\title{
Optimized operation of regional reserve forces in a changing future security environment
}

\author{
Seungbong Yang*
}

\section{ABSTRACT}

The Republic of Korea Reserve Forces (ROKRF), established in 1968, continue to function through continuous changes such as improving laws and systems and optimizing organizations while complying with social and policy changes. However, the reduction of standing forces, changes in the operating environment, and the reduction of reserve forces required to carry out operations require the re-establishment of the concept of operation of regional reserve forces. In this study, we aimed to diagnose the phenomenon of regional reserve groups and derive an optimized operation plan for regional reserve groups in consideration of changes in the future security environment, operation support system, and law and order system. The operating system presented the mission of establishing local reserve forces suitable for the operating environment, organization, and organization maintenance for the future as well as maintenance and development of combat power through education and training. Finally, in the law and order system section, a plan to revise laws was proposed in consideration of the task of operating and constructing regional reserve forces and re-establishing them.

Keywords : regional reserve forces, reserve power, security environment, operating system, operational continuity support system, armed forces organization act

* (First Author) Researcher at National Defense University's Reserve Power Research Center and Wonkwang University, Department of Military Sciences and Art, Ph.D. Candidate, 7co-zzang@hanmail.net, https://orcid.org/0000-0001-7955-1187 


\section{I. 서론}

우리나라의 예비군은 지난 1968년 북한이 무장공비를 남파하여 주요 암살요인과 청와대 타격을 목표한 1-21사태를 계기로 창설되었다(Joo, Y. Y., 2017). '내 고장은 내가 지킨다. 일하면서 싸우 자'라는 슬로건 하에 1968년 4월 1일 창설되어 오늘날까지 국가방위와 경제발전의 주축으로서 임 무를 수행하여 왔다. 그러나 창설 당시와 비교하여 변화된 사회 안보환경은 예비군에게도 변화를 요구하고 있다. 특히, 현 정부 들어 ‘평화공존’과 ‘공동번영’을 통한 통일을 지향하면서 2018년 4월 남·북 정상회담에서 ‘판문점 선언’과 그해 9월 남·북 정상회담의 '평양 공동선언' 등을 토대로 남북관계 개선 및 긴장 완화를 추진해 왔다. 그러나 미 - 북 하노이 회담 결렬 이후 북한과의 관계 는 선언 이전으로 돌아갔다. 북한은 경제난이 가중되는 상황에서도 남북연락사무소 폭파, 서해 공 무원 피격 등 도발을 강행하였으며 최근에는 한미연합훈련을 이유로 노골적인 군사도발 의지를 표 명하는 등 북한의 군사적 위협요인은 지금도 계속되고 있다. 우리 군은 북한의 군사적 위협에 맞서 성공적으로 대북억제력을 발휘하여 왔다. 세계적인 군사력 건설추세에 따라 병력 위주의 재래식 군 사력 건설에서 기술집약적인 첨단 과학군으로 거듭나기 위해 국방개혁을 추진하고 있으며 상비병 력 감축에 따라서 예비전력 내실화를 추진하고 있다.

한편, 우리나라의 경제발전이 가속화됨에 따라서 인구감소, 도시지역 인구집중 현상 등 다양한 사회문제가 발생하고 있다. 인구의 감소는 가용 병력자원의 감소, 예비군 감소로 이어져 예비군 운 영에 어려움이 예상되며 도시지역 인구 집중화는 이러한 현상을 가속화 하고 있다. 예비군 창설 53 주년이 되는 현시점에서 대 - 내외 안보환경에 대한 불확실성과 코로나 19 와 같은 비전통 안보위협 증가, 상비병력의 감소는 안보위협에 대한 예비군의 역할 확대를 요구하고 있어 미래 안보환경에 능동적으로 대응하고 운영할 수 있는 지역예비군에 대한 검토가 필요하다. 이에 최근 국내 연구는 재난발생이나 해외파병 시 예비군의 활용방안을 제안하고 있으나(Choi, S. H., 2020; Park, J. G., 2020), 여전히 관련 연구가 부족한 실정이다. 따라서 본 연구는 상기한 안보 및 사회적 환경변화를 고려하여 지역예비군 제도를 검토하고, 미래 지역예비군의 운영과 관련하여 발전방안을 모색하는 데 그 목적을 두고 있다. 국방부와 육군본부에서 발표한 국방개혁 2.0과 예비전력 비전 2030에 따른 지역예비군의 정책적 방향을 연구하고 우리가 맞이하고 있는 변화되는 안보 - 사회환경을 고려하 여 미래 지역예비군 운영에 대한 방안을 제시하였다. 또한, 연구의 목적달성을 위해 선행연구에 대 한 문헌 조사방법과 함께 우리 군의 예비전력과 관련된 정책을 주도하고 있는 국방부와 육군본부 의 실무자료에 대한 분석을 병행하였다. 문헌 고찰은 최근 5 년 간 출판된 국내 연구자료 중 지역예 비군 관련 주제를 중점적으로 검색하여 내용분석을 진행하였다. 급변하는 세계 및 국내정세와 관련 된 시사점을 보완하기 위해서는 최근 발표되는 각종 언론 보도 등을 참조하였다. 


\section{ㅍ. 이론적 배경}

\section{1 예비전력}

지역예비군을 이해하기 위해서는 예비전력을 먼저 이해해야 하는데 지역예비군은 예비전력의 구성요소이며 예비전력이라는 틀에서 이해가 가능하기 때문이다. 합동참모본부의 군사용어 사전에 는 “예비전력이란 상비전력에 대응하는 개념으로서, 국가잠재력을 전력화함으로써 생성되는 군사 력을 말한다. 전시에 동원할 수 있는 인적 - 물적 자원과 전시·평시 지역방위를 위한 인적·물적 능력을 포함한다.”1)고 정의하고 있다. 구체적으로 예비전력은 “유사시 동원을 통해 전력화되는 잠 재적인 군사적 요소로서 넓은 의미와 좁은 의미의 개념으로 구분하는데 넓은 의미로는 상비전력을 군사행동이 가능한 현존 즉응 군사력이라 할 때 상비전력 이외의 인적-물적 자원으로 구성되는 총체적 전쟁수행 능력을 의미하며 좁은 의미로는 군사동원을 통해 전력화할 수 있는 전력으로서 전시 상비군 증 - 창설 지원, 손실 - 보충되는 인적 - 물적 자원과 전 - 평시 지역방위를 위해 소요되 는 인적 - 물적 자원"을 포함한다. 한편, 예비전력의 구성은 “인적자원과 물적자원으로 구분할 수 있으며, 국가 차원에서의 적용과 군사 차원에서의 적용에 따라 그 범주를 달리한다. 군사력 건설 측면에서는 개념적 요소인 인적 및 물적자원과 더불어 정책과 제도를 포함할 수 있으며 예비전력 이 실체적인 군사력으로 형성되기까지는 각 구성요소에 따라 군사와 민간의 영역으로 구분"할 수 있다(Kang, Y. G., 2019, p. 16).

이와 같은 견해들을 종합해 보면 예비전력의 구성요소는 상비전력 이외의 인적 - 물적 자원과 제 도 - 정책 등을 포함한 유- 무형의 잠재전력이라 할 수 있으며 동원을 통해 형성되는 군사적 능력 을 예비전력이라고 정의할 수 있겠으며 지역예비군은 예비전력의 인적요소로서 비상시 전투력을 발휘할 수 있도록 조직된 군사집단이라고 할 수 있다.

\section{2 지역예비군의 필요성과 특징}

예비군이란 평시에는 생업에 종사하다가 유사시 동원되어 현역 군부대의 확장이나 지역방위 등 국방의 의무를 수행하기 위해 조직된 부대 또는 개인이며 지역예비군은 직장예비군이 아닌 자로 편성된 예비군으로 전쟁이나 긴급 상황 발생 시 지역을 방위하기 위해 편성되며, 행정구역 단위로 편성함을 원칙으로 한다고 합동참모본부의 군사용어 사전에 명시되어 있다.2) 즉, 지역예비군은 평 시에는 경제발전에 기여하면서 적의 침투 또는 침투 징후 발생, 기타 긴급 상황 시 동원되어 읍 면 - 동 단위 지역을 방위하는 집단이라고 할 수 있다. 지역예비군이 필요한 이유는 첫째, 적과의 군사력 균형을 유지하고 둘째, 후방지역에서 통합방위작전을 수행하며 셋째, 전시 상비전력에 대한

1) 합동참모본부(2020). 합동 - 연합작전 군사용어사전. 서울: 합동참모본부. p. 322.

2) 합동참모본부(2020). 합동 - 연합작전 군사용어사전. 서울: 합동참모본부. p. 622 p. 623. 
작전지속지원 유지 및 지원에 기여하고 넷째, 평시 자연 재난으로부터 발생되는 국민의 재산과 생 명을 보호하고 피해를 막는 등의 임무를 수행하기에 국가 잠재전력인 지역예비군이 필요하다.

지역예비군의 특성을 살펴보면 첫째, 지역예비군은 거주지 중심으로 조직 편성되어 있으며 부대 별로 자원 및 편성 규모가 상이하다. 둘째, 지역예비군은 그 지역 주민으로 편성되어 지형과 환경에 익숙하고 주민과 협조된 작전 수행이 가능하다. 셋째, 지역예비군은 평소에는 각자의 생업에 종사 하다가 동원 시에 소집되기 때문에 지역예비군을 운용하는 데 비용이 적게 든다. 예비전력은 국방 비의 $0.4 \%$ 정도의 비용을 사용하고 있는데 지역예비군의 경우 지방자치단체에서 지원하는 육성 지원금을 활용하고 있기에 아주 적은 국방비가 소요된다. 넷째, 지역예비군은 직업, 신분, 연령 등 이 다양하고 자질과 능력의 차이가 발생하게 되므로 예비군 운용 시 자원의 능력을 고려하여 적절 하게 편성하고 활용해야 한다. 다섯째, 지역예비군은 현역과는 다르게 급식 및 수송차량 등 작전지 속지원을 지방자치단체로부터 지원받는다. 평소에 지방자치단체와 협조된 작전지속지원 체계를 구 축하여 상황발생 시 활용할 수 있는 시스템을 만들어야 한다. 여섯째, 지역예비군은 평소 민간인 신분으로 군법의 적용을 받지 않으며, 동원 시에만 예비군법에 따라 통제할 수 있는 특성이 있다. 요약하면, 지역예비군은 평시에는 일반 시민으로 생업에 종사하다가 유사시 동원되어 지역방위체 계를 구축하여 방위하는 지역 안보 지킴이인 동시에 국가경제의 주역인 것이다.

\section{3 지역예비군의 특징과 운영}

\subsection{1 임무 및 운용 측면}

예비군의 임무는 ‘전시, 사변, 기타 이에 준하는 국가비상사태하에서 현역 군부대 편성이나 작전 소요를 위한 동원에 대비하고, 적 또는 반국가단체의 지령을 받은 무장공비가 침투하거나 침투할 우려가 있는 지역에서 적이나 무장공비의 소멸, 무장소요가 있거나 그 우려가 있는 지역 안에서 경 찰력만으로 그 소요를 진압 또는 대처할 수 없는 경우에 한해 무장소요의 진압, 중요시설 - 무기고 및 병참선 등의 경비, 민방위 기본법에 의한 민방위 업무의 지원'으로 현행법에 명시되어 있다.3) 이와 같은 예비군의 임무는 시대의 안보상황과 국내·외의 정세 등을 고려하여 변화되어 왔는데 예비군의 임무의 변천과정을 정리하면 다음과 같다.

$<$ Table $1>$ Changes in reserve forces' duties

\begin{tabular}{c|ll}
\hline Year & & Missions \\
\hline \hline \multirow{3}{*}{1961} & $\begin{array}{l}\text { Local defense } \\
\text { • Communication line security } \\
\end{array}$ & \\
\hline
\end{tabular}

3) 국방부 예비군법, 법률 제 16585 호(2019. 11. 26.) 제2조(임무). 


\begin{tabular}{|c|c|c|}
\hline 1968 & - Enemy or armed defense is extinguished & $\begin{array}{l}\text { - Important facilities and Communication } \\
\text { line security }\end{array}$ \\
\hline 1970 & $\begin{array}{l}\text { - Preparing for mobilization } \\
\text { - Expense for important facilities and } \\
\text { communication lines }\end{array}$ & - Enemy or armed defense is extinguished \\
\hline 1980 & $\begin{array}{l}\text { - Preparing for mobilization } \\
\text { - Expense for important facilities and } \\
\text { communication lines } \\
\text { - Civil defense support }\end{array}$ & $\begin{array}{l}\text { - Enemy or armed defense is extinguished } \\
\text { - Suppression of armed desire }\end{array}$ \\
\hline
\end{tabular}

* Source: adapted from Lee, W. H. (2015, p. 222).

현재 약 275만 명에 달하는 예비군의 임무는 1980년에 만들어진 동원 대비, 적 또는 무장공비 소 멸, 중요시설 및 병참선 경비, 무장소요 진압, 민방위 업무 지원 5가지로 규정되어 있는데 1961년과 비교 시 임무의 변화는 거의 없으며 대침투작전 시 예비군 동원 등 군사적 위협 위주의 임무만 명 시되어 있으며 각종 재해재난, 테러 등 다양한 위협에 효율적 대응을 위한 임무는 미정립되어 있다. 무장소요 진압과 같은 국민정서와 현실을 고려하지 않은 임무도 포함되어 있다. 따라서 1980년 이 후 변함없는 예비군의 임무와 역할을 시대변화에 맞게 조정해야 하며 미래 예비군 운용까지 고려 하여 예비군의 임무에 포함해야 한다.

지역예비군 운용 측면을 살펴보면, 예비군 자원은 감소하고 있으며 <Table $2>$ 와 같이 지역예비 군부대는 ' 24 년까지 통폐합을 진행하고 있다. 현역부대는 부대개편을 통해 여단 중심의 부대 구조 로 개편 중에 있어 작전 책임지역은 2 3배 확장되었다.

$<$ Table 2> Status of integration and closure of regional reserve forces ${ }^{4}$

\begin{tabular}{c|c|c|c|c|c}
\hline Division & $\begin{array}{c}2020 . \\
\text { ('21. 1. 1.) }\end{array}$ & $\begin{array}{c}2021 . \\
\text { ('22. 1. 1.) }\end{array}$ & $\begin{array}{c}2022 . \\
\text { (‘23. 1. 1.) }\end{array}$ & $\begin{array}{c}2023 . \\
\text { (‘24. 1. 1.) }\end{array}$ & $\begin{array}{c}2024 . \\
\text { ('25. 1. 1.) }\end{array}$ \\
\hline \hline \# of troops & 3,049 & 2,838 & 2,666 & 2,473 & 2,290 \\
\hline
\end{tabular}

예비군부대 감소와 책임지역 확장을 고려한 예비군부대 조직편성에 대한 개선이 필요하지만, 자 원 규모에 관계없이 일률적인 편성으로 전투력 발휘가 제한되며 이에 따른 조직편성 보완이 필요 하다. 또한, 농·어촌 지역은 대도시 지역과 비교하면 자원이 부족해 간부직위에 병사를 보직하고 있으며 병사의 경우는 희소특기가 부족해 편성이 제한되는 등 전투력 발휘를 위한 대책이 필요하 다. 한반도 대 - 내외 안보정세와 사회환경의 변화를 고려한 예비군 운영계획 수립이 필요하며 더 나아가 미래에 부족한 상비전력을 보강하고 실효성 있는 전투수행 방안을 구체화하는 대책이 필요 하다.

4) 육군본부(2018). 예비전력 비전 2030. 계룡, p. 3장-14-6. 


\subsection{2 교육훈련 측면}

예비군 교육훈련이란 병역법과 예비군법에 따라 예비군으로 편성된 자에 대한 교육훈련과 예비 군 관련 업무 종사자를 대상으로 실시하는 간부교육이다.5) 예비군훈련 대상과 시간은 4개 훈련유 형으로 편성되어 있다(Table 3).

$<$ Table 3> Target and time of reserve forces training6)

\begin{tabular}{|c|c|c|c|c|c|c|c|}
\hline & \multirow{2}{*}{\multicolumn{2}{|c|}{ Division }} & \multicolumn{2}{|c|}{$\begin{array}{c}\text { Mobilization reserve forces } \\
\text { training }\end{array}$} & \multicolumn{2}{|c|}{$\begin{array}{l}\text { Regional reserve } \\
\text { forces training }\end{array}$} & \multirow{2}{*}{$\begin{array}{l}\text { Preliminary } \\
\text { time }\end{array}$} \\
\hline & & & Mobilization & $\begin{array}{l}\text { Mobilization } \\
\text { undesignated }\end{array}$ & Basic & Fieldwork & \\
\hline \multicolumn{3}{|c|}{ New discharged person } & & & & & 16 hours \\
\hline \multirow{4}{*}{ Solider } & \multirow{2}{*}{$\begin{array}{c}1^{\text {st }} \text { to } 4^{\text {th }} \\
\text { years }\end{array}$} & $\begin{array}{c}\text { Mobilization } \\
\text { designated }\end{array}$ & $\begin{array}{l}2 \text { nights and } \\
3 \text { days }\end{array}$ & & & & 132 hours \\
\hline & & $\begin{array}{l}\text { Mobilization } \\
\text { undesignated }\end{array}$ & & $\begin{array}{c}2 \text { nights and } 3 \\
\text { days (32 } \\
\text { hours) }\end{array}$ & & & $\begin{array}{l}128 \text { hours } \\
\text { (132 hours) }\end{array}$ \\
\hline & $\begin{array}{c}5^{\text {th }} \text { to } 6^{\text {th }} \\
\text { years }\end{array}$ & $\begin{array}{l}\text { Mobilization } \\
\text { undesignated }\end{array}$ & & & 8 hours & $\begin{array}{c}12 \text { hours } \\
(6 \mathrm{H} \times 2)\end{array}$ & 140 hours \\
\hline & \multicolumn{2}{|c|}{$7^{\text {th }}$ to $8^{\text {th }}$ years } & \multicolumn{4}{|c|}{ Take extra training for uncompleted training } & 160 hours \\
\hline \multirow{3}{*}{ Officer } & \multirow{2}{*}{$\begin{array}{c}1^{\text {st }} \text { to } 6^{\text {th }} \\
\text { years }\end{array}$} & \begin{tabular}{|c|} 
Mobilization \\
designated
\end{tabular} & $\begin{array}{l}2 \text { nights and } \\
3 \text { days } \\
\end{array}$ & & & & \\
\hline & & $\begin{array}{l}\text { Mobilization } \\
\text { undesignated }\end{array}$ & & $\begin{array}{l}2 \text { nights and } \\
3 \text { days }\end{array}$ & & & \\
\hline & \multicolumn{2}{|c|}{$\begin{array}{c}7^{\text {th }} \text { years to retirement } \\
\text { age }\end{array}$} & \multicolumn{4}{|c|}{ Take extra training for uncompleted training } & \\
\hline
\end{tabular}

지역예비군훈련은 5 6년차를 대상으로 예비군법에 따른 임무수행을 위한 필수과목(제)을 실시 하는 기본훈련과 거주지나 직장 일대에서 실시하는 작계훈련으로 구분되다. 기본훈련은 개인 기본 전투기술 숙달에 중점을 두고 안보교육, 사격, 기타과제(수임군부대장 판단)를 연 1회 8시간 예비군 훈련대7)에서 실시한다. 오전 4시간은 공통과목(안보교육, 사격)을 훈련하고 오후 4시간은 기타과제 훈련을 실시한다. 기타과제는 수임군부대장 판단에 따라서 과제를 선택하는데 부대특성에 부합된 훈련을 실시할 수 있다는 긍정적인 측면도 있으나 제한된 시간 안에 측정식 합격제 평가를 해야하 며, 우수자에 대해 조기퇴소 인센티브를 부여하는 것을 고려 시 단순 측정이 가능한 병기본 과제위

5) 국방부 예비군 교육훈련 훈령. 훈령 제2496호(2020. 12. 31.) 제2조(정의) 1항.

6) 국방부 예비군 교육훈련 훈령. 훈령 제2496호(2020. 12. 31.) 제8조(훈련대상 및 시간) 2항

7) 국방개혁에 따른 군 구조 개편과 연계하여 육군에서는 '24년까지 대대 단위(202개소) 지역예비군훈련장을 여단 단위(40개 소)로 통합하여 과학화훈련장으로 설치하는 것을 추진 중에 있다. 
주로 선정할 우려가 있다. 또한, 비군사적 위협에 대비한 임무수행을 고려하여 재해 - 재난 등에 대 비한 훈련과제 등을 반영할 필요성도 증대되고 있다. 작계훈련은 지역방위 작전수행능력 배양에 중 점을 두고 전 - 후반기로 구분하여 연 2회씩 6시간 작계지역에서 실시한다. 입소, 식사, 총기수령, 작계지역 이동 등의 시간 고려 시 실질적으로 훈련하는 시간은 2 시간 내외로 훈련의 성과가 미미할 것으로 보이며 지역방위작전이 목진지, 검문소 운용 위주에서 기동타격 임무로 변화됨에 따라서 이 에 맞는 훈련방법에 대한 보완이 요구된다.

국방개혁 2.0 추진에 따라 상비병력과 예비군의 규모가 지속적으로 축소되고 있는 시점에서 지 역예비군 정예화를 위해서 작전환경 변화를 고려한 훈련체계, 방법 등에 대한 검토도 필요하며 전 투기술에 대한 예비군들의 망각주기 등도 고려하여 예비군훈련 주기에 대해서도 검토가 필요하다.

\section{3 .3 작전지속지원 측면}

지역예비군 작전지속지원의 책임은 지방자치단체의 장에게 있으며, 현행법상 지역방위작전과 관 련된 급식 - 수송 - 통신 - 의료 - 장비 · 물자 및 전투시설에 대해 지원하며8) 지역방위작전 간 예비 군에 대한 작전지속지원은 군과 지방자치단체(통합방위지원본부), 직장의 장 책임하에 실시한다.9) 현재 지역예비군부대의 작전지속지원은 읍·면 - 동에서 담당하고 있다. 행정기관의 지원은 예산 의결을 통해서 이루어지는데 읍·면 - 동은 예산의결권이 없어 의결권이 있는 시· 군· 구에서 대 대의 파트너가 되어 지원하였다. 문제는 대대별 1 개의 시·군 - 구를 담당했지만, 국방개혁에 따라 여단별 3 개 대대로 편성하여 편제 일원화를 추진하고 있어 2 개 이상의 시·군 - 구로 작전지역이 확장되고 있다. 또한, 지역예비군부대는 예비군 자원이 감소하고 있어 ' 25 년까지 통 - 폐합을 추진 하는 데 자원이 적은 읍 - 면의 지역예비군부대는 3 6개로 책임 지역이 확대되고 있다는 점이다.

이에 따르는 문제점으로 시 · 군 · 구 방위지원본부 주도의 통합된 작전지속지원이 제한되며, 읍 • 면 - 동 통합중대 편성 시 관련 행정기관의 지원책임 설정이 불분명하다. 자원부족지역으로 전환되 는 예비군에 대한 지원체계도 정립이 되어 있지 않으며 지방자치단체 육성지원금에 지나치게 의존 함에 따라 부대별 전투물자 보유수준에서도 차이가 크게 발생하고 있다. 따라서 지역예비군부대의 변화 양상을 고려하여 효율적인 작전지속지원체계 구축이 필요하며 더 나아가 비전통적 위협에 대 비한 미래 지역예비군에 대한 작전지속지원체계에 대한 검토가 필요하다.

\subsection{4 법령 및 제도 측면}

동원 및 예비전력과 관련된 법령은 헌법을 비롯해 국군조직법, 예비군법, 통합방위법, 비상대비

8) 예비군법 시행령 제 32 조(예비군의 육성 - 지원) (1) 법 제 14 조의 3 제 1 항에 따른 예비군의 육성 - 지원에 관한 사항은 다음 각 호화 같다. 4. 지역방위작전과 관련된 급식·수송·통신 - 의료 - 장비·물자 및 전투시설 지원 (2) 동원된 지역예비군에 대한 급식은 작전지역을 관할하는 지방자치단체의 장이 지원하고 직장 예비군에 대한 급식은 해당 직장의 장이 지원한다.

9) 합동참모본부(2019). 지역방위작전 지침서, 서울, p. 6장-10-1. 
자원관리법, 병역법, 계엄법, 징발법, 전시 자원동원에 관한 법률, 국지전 등 위기극복을 위한 부분 동원에 관한 법률 등이 있다. 이러한 법체계는 대부분 동원과 관계되는 것으로서 국방부를 비롯해 행정안전부, 산업통산자원부, 보건복지부, 환경부 등 전 부처와 관련되어 있다. 연구범위를 지역예 비군으로 한정하고 있기에 지역예비군과 관계된 법령인 예비군법, 국군조직법에 대해서 살펴보면 다음과 같다.

예비군법은 지역방위를 목적으로 하는 지역예비군 설치, 조직, 편성, 동원 등에 관한 사항을 규정 한 법이다. 예비군은 제2조(임무)에 근거하여 임무를 수행했는데 법이 만들어질 당시 작전환경과 지금은 많은 차이가 있어 변화요소를 고려한 검토가 필요하다. 제2조(임무) 2항에 명시된 침투한 무장공비 소멸은 1996년 강릉 무장공비 침투사건 이후 무장공비 침투사건은 발생하지 않았으며(앞 으로도 없으리라는 것은 아니다) 후방지역에 무장공비 침투 시 국가비상사태(통합방위사태) 선포 에 따른 예비군 동원은 자동으로 될 것이라 1 항의 임무와 동일하여 조정이 필요하다. 3 항에 명시된 무장소요 진압을 위해 예비군이 동원된 사례는 없으며 국민의 정서를 고려 시 현실성 있게 개선해 야 할 필요가 있다. 또한, 4항 무기고의 경비는 과거 경찰서에서 무기를 관리하던 때의 임무이며 현재의 예비군 임무와는 동떨어져 있어 이에 대한 검토가 필요하다. 이외에도 변화된 안보환경을 고려하여 재해 - 재난, 테러 등 국가재난 등의 비군사적 지원과 현역감축에 따른 국제평화유지활동 등 변화추세에 맞는 임무에 대한 검토 또한 필요하다.

국군조직법은 국방의 의무를 수행하기 위한 국군의 조직과 편성의 대상을 규정하고 있으며 국군 의 범위, 군사력의 건설과 운용에 관한 기초를 제공하고 있으나 예비군은 이러한 국군조직에 포함 되지 않는다. 제 2 조(국군의 조직) 1 항은 국군은 육 - 해 - 공군 및 해병대로 명시되어 있으며 제 4 조 (군인의 신분 등) 1 항은 전 - 평시를 막론하고 군에 복무하는 사람으로 명시되어 있다. 동원예비군 은 전시 병역법에 의해 동원되어 군에 복무하므로 군인에 속하지만, 예비군법에 의해 동원된 지역 예비군은 동원 시 민간신분이 적용된다. 즉, 지역예비군은 군 조직으로 활용되고는 있으나 국군 범 주에는 포함될 수 없다. 시대변화에 따른 역할을 확장하고 상비군 대체임무 수행 등 상비군과 더불 어 국방의 핵심적인 역할을 하는 조직으로 거듭나기 위해 예비전력정책에 전반적으로 영향을 미치 는 국군조직법에 대한 개선이 필요하다.

\section{III. 연구방법}

\section{1 선행연구 검토}

예비전력과 관련 연구는 동원체제와 예비군제도 개선에 관한 것이었다. 2005년 참여정부의 국방 개혁 발표 이후 국방개혁과 연계하여 많은 연구가 다양하게 이루어지고 있으나 미래 안보환경을 
고려한 지역예비군과 관련된 연구는 다소 미흡하였다. 지역예비군과 관련된 선행연구를 살펴보면 다음과 같다.

Lee, K. P. (2017)은 미래 지역방위작전 환경 변화요인을 분석하고 예비군 운용개념을 작전적인 측면과 작전지속지원 측면에서 검토하여 발전방안을 제시하였다. 지역방위작전 지침서를 기초로 현재 수행하고 있는 지역방위작전에 대한 발전사항을 통해 효율적인 지역예비군 운용체계를 제시 하였으나, 현재 추진 중인 국방개혁과 자원감소 등 미래 변화되는 요소에 대한 논의가 부족하다는 점은 한계가 있다. Jeong (2018)은 통일 이후의 안보환경 및 위협분석을 통해 통일 한국의 적정 예 비군 규모를 판단하였으며 예비군제도 정예화(Choi \& Park, 2014)를 위해 통합병역복무제도, 예비 군 지휘관리체계와 동원체계 구축, 예비군 조직편성 및 복무제도 정립 등을 제시하였다. 특히, 통일 이후에는 현재의 지역예비군부대를 해체하고 현역과 예비군이 혼합 편성된 지역방위사단을 존속

$<$ Table $4>$ Summary of studies about Korean regional reserve groups

\begin{tabular}{|c|c|c|}
\hline Study & Research data & Main contents \\
\hline $\begin{array}{l}\text { Shin. D. \& } \\
\text { Jung, C. Y. } \\
\text { (2016) }\end{array}$ & $\begin{array}{l}\text { Suggestions } \\
\text { reserve forces through examples } \\
\text { of U.S. reserve forces' } \\
\text { development }\end{array}$ & $\begin{array}{l}\text { Through a case study of the development of the } \\
\text { U.S. reserve forces, the revision of the Armed } \\
\text { Forces Organization Act and the introduction of } \\
\text { total power to elite reserve forces are argued. }\end{array}$ \\
\hline $\begin{array}{l}\text { Lee, K. P. } \\
\quad(2017)\end{array}$ & $\begin{array}{l}\text { Future local defense operation } \\
\text { development plan }\end{array}$ & $\begin{array}{l}\text { Presentation of the concept of operation of local } \\
\text { defense operations and the development plan of } \\
\text { operation continuity in consideration of changes in } \\
\text { the future operating environment. }\end{array}$ \\
\hline $\begin{array}{l}\text { Jeong, J. S. } \\
\text { (2018) }\end{array}$ & $\begin{array}{l}\text { Korea's preparation after } \\
\text { reunification with reserve power } \\
\text { operation }\end{array}$ & $\begin{array}{l}\text { After the reunification of the North and South } \\
\text { Korea, considering the security situation and } \\
\text { conditions on the Korean Peninsula, the appropriate } \\
\text { size of reserve forces and the presentation of a new } \\
\text { reserve force operation system are presented. }\end{array}$ \\
\hline $\begin{array}{l}\text { Kang, Y. G. } \\
\text { (2019) }\end{array}$ & $\begin{array}{l}\text { Direction of promotion of } \\
\text { reserve power policy according } \\
\text { to changes in the security } \\
\text { environment in the } 21^{\text {st }} \text { Century }\end{array}$ & $\begin{array}{l}\text { Present detailed issues and future-oriented } \\
\text { development directions for each core element of the } \\
\text { reserve power policy. }\end{array}$ \\
\hline$\underset{\text { (2019) }}{\text { Kim, M. S. }}$ & $\begin{array}{l}\text { Following the promotion of } \\
\text { national defense reform in the } \\
\text { direction of the wartime power } \\
\text { generation }\end{array}$ & $\begin{array}{l}\text { Analysis of the problems of the operation continuity } \\
\text { support system of the regional reserve forces } \\
\text { during the exhibition and presentation of plans for } \\
\text { operation and development. }\end{array}$ \\
\hline $\begin{array}{l}\text { Jeong, H. S. } \\
\text { (2019) }\end{array}$ & $\begin{array}{l}\text { In connection with Defense } \\
\text { Reform } 2.0 \text { plan for promoting } \\
\text { elite reserve power }\end{array}$ & $\begin{array}{l}\text { Proposed a plan to promote the elite reserve forces } \\
\text { in preparation for future security threats. }\end{array}$ \\
\hline $\begin{array}{l}\text { Koo \& Park } \\
\quad \text { (2019) }\end{array}$ & $\begin{array}{l}\text { Power generation of reserve } \\
\text { forces in Singapore through the } \\
\text { case of the reserve forces } \\
\text { system }\end{array}$ & $\begin{array}{l}\text { It analyzes the Singapore reserve forces system } \\
\text { with similarities to Korea and proposes a plan to } \\
\text { promote the elite reserve forces. }\end{array}$ \\
\hline
\end{tabular}


시키는 개념을 제시하는 등 미래의 지역예비군 편성과 운영개념에 대해 제시하였다. 이 연구는 통 일 이후 한국군 예비전력에 관한 첫 번째 학위논문으로 의미가 있다.

Kang (2019)는 예비전력정책을 연구하여 분석하고 현재 한국의 예비전력이 상비전력의 대체전 력으로서 임무를 수행하는데 제한되는 문제점과 주요 국가의 예비전력정책이 주는 시사점을 도출 하였다. 예비전력의 역할을 정립하고 운용 - 관리 - 법령 및 제도적인 측면에서 연구하여 예비전력 정책의 미래지향적인 추진 방향을 제시하였다. Kim, M. S. (2019)는 국방개혁 추진과 연계하여 전 • 평시 예비전력 발전방향을 지역예비군 작전지속지원 측면에서 문제점과 발전방안을 제시하였다. 특히, 지방자치단체 협조 중심의 지속지원 체계 발전과 실효성 있는 무기 - 장비 - 탄약 및 급식지 원에 대해 연구하였다. 지역예비군 운영 측면과 미래 안보환경을 고려하지 않은 점은 지역예비군 연구에 대한 한계가 있지만, 그동안 논의되지 않았던 지역예비군 작전지속지원에 관한 연구라는 점 에서 의의가 있다. Jeong, H. S. (2019)는 국방개혁 2.0과 연계하여 추진되고 있는 예비전력 정책의 현주소를 진단하고 급변하는 한반도의 안보환경 속에서 바람직한 예비전력 정예화 추진방안을 제 시하였다. 예비전력 문제점을 제시하고 임무 - 규모 - 예산 - 법령 개정소요 등 정예화를 위한 발전 방안을 제시하였다.

Shin and Jung (2016)은 미국 예비군이 성공적으로 자리매김할 수 있었던 것은 1920년 국가방위 법 제정과 1973년 모병제 전환에 따른 총체 전력정책 도입의 결과로 분석하고 예비전력 정예화를 위해 국군조직법 개정과 총체 전력정책 도입을 제시하였다. Koo and Park (2019)는 예비전력 발전 을 위해 선진화된 싱가포르 예비군 제도를 연구하여 예비전력 정예화 소요들을 발굴하였으며 발전 방안으로 예비군 임무와 역할 확대, 정예 예비군 확보 및 육성, 예비군 보상 및 복지, 예비군 인식개 선 및 예산 확대 방안 등을 제시하였다.

이상과 같은 선행연구는 국방개혁과 연계하여 예비전력 정예화에 초점을 둔 연구 경향이 나타나 고 있다. 상비전력의 대체전력으로 예비전력의 내실화를 논하고 있어 지역예비군 운영에 관한 연구 로는 부족하다고 볼 수 있으며, 외국의 예비전력에 관한 연구도 동원 위주 부대의 정예화에 중점을 두고 있다. 또한, 지역예비군을 연구한 논문도 현재의 모습 속에서 발전방안을 제시했기에 미래 지 역예비군 연구와는 차이가 있다. 본 논문은 국방개혁과 미래 안보환경의 변화를 고려하여 후방지역 에서 핵심적인 임무를 수행하는 지역예비군의 미래지향적인 발전 방향을 제시함으로써 연구의 차 별화를 시도하였다.

\section{2 분석의 틀}

1968년 창설된 예비군은 사회적 - 정책적 변화에 순응하면서 법령 및 제도 개선, 조직 - 편성 최 적화 등 지속적인 변화를 통해 오늘에 이르고 있다. 그러나 국방개혁 추진에 따른 상비전력의 감축, 작전환경의 도시화, 작전 수행에 필요한 예비군 자원의 감소는 지역예비군 운영개념에 대한 재정립 
을 요구하고 있다. 따라서 변화되는 미래 안보환경 변화를 고려하여 지역예비군 최적화 운영방안을 검토할 필요가 있다. 상비전력과는 다르게 지역예비군 운영에 직접적인 영향은 대내적 요인들에 의 해 주로 결정된다. 이를 실현 가능한 군사력을 운영한다는 관점에서 지역예비군 최적화 운영을 위 한 핵심과제를 운영체계, 작전지속지원체계, 법과 제도로 선정하였다. 이를 위한 분석의 틀은 $<$ Figure $1>$ 과 같다.

A theoretical background study on reserve power reserve

\begin{tabular}{|c|c|c|c|c|}
\hline \multirow{3}{*}{$\begin{array}{c}\text { Changes } \\
\text { in the } \\
\text { security } \\
\text { environment }\end{array}$} & \multicolumn{3}{|c|}{$\begin{array}{c}\text { Derivation of key tasks for optimizing regional reserve } \\
\text { forces }\end{array}$} & \multirow{3}{*}{$\begin{array}{l}\text { Analysis } \\
\text { of regional } \\
\text { reserve } \\
\text { forces }\end{array}$} \\
\hline & Operating system & $\begin{array}{c}\text { Operation } \\
\text { support system }\end{array}$ & $\begin{array}{l}\text { Acts and } \\
\text { systems }\end{array}$ & \\
\hline & $\begin{array}{l}\cdot \text { Re-establishing } \\
\text { mission } \\
\cdot \text { Organization } \\
\cdot \text { Education \& } \\
\text { training }\end{array}$ & $\begin{array}{l}\cdot \text { Equipment and } \\
\text { supplies } \\
\cdot \text { Meals }\end{array}$ & $\begin{array}{l}\text { - Military } \\
\text { Organization } \\
\text { Act } \\
\cdot \text { Integrated } \\
\text { reserve power } \\
\text { legislation }\end{array}$ & \\
\hline
\end{tabular}

Presenting the direction of development on the optimized operation of future regional reserve forces

$<$ Figure 1> Analytical framework

우선, 제시된 연구흐름도에서 객관적이고 현실적인 분석을 위해 지역예비군의 현상과 안보환경 의 변화를 살펴보고 지역예비군 최적화 운영을 위한 핵심과제 3가지를 도출하였다. 예비군의 임무 와 역할이 전·평시 및 국가비상 시 군사·비군사 임무수행과 관련하여 적절성을 살펴보고 전투력 유지를 위한 지역예비군의 조직편성 및 교육훈련과 연계하여 운영체계를, 지역예비군에게 지급되 는 장비 및 물자와 통합지원본부에서 지원하는 급식을 전투력 발휘 측면에서 작전지속지원체계를 살펴보고, 마지막으로 국군의 일원에 포함되기 위한 국군조직법 개정과 다양한 위협에 효율적으로 대응하기 위한 예비전력 법령 통합을 법과 제도에서 연구하여 미래 지역예비군 최적화 운영에 관 한 발전 추진방향을 제시할 것이다. 


\section{IV. 미래 지역 예비군의 발전전략}

\subsection{1 세기 안보환경의 변화}

최근 우리 한반도를 둘러싼 대 - 내외 안보상황은 매우 복잡하다. 주변국들은 자국 우선주의를 내세우며 첨단 군사력을 지속적으로 확충해 나가고 있으며, 해상과 공중은 물론 우주 - 사이버 등 으로 군사영역을 확장해 나가고 있다. 또한, 코로나 19 , 재난, 테러 등 초국가적 - 비군사적 위협들 이 국가안보의 도전 요인으로 대두되고 있는 현실이다. 특히 코로나 19 의 확산, 미 · 중 간 전략적 경쟁 등으로 역내 안보구도의 유동성과 불확실성은 더욱 증대되고 있다.

\subsection{1 한반도 안보환경 변화와 위협의 다변화}

동북아에서의 미국과 중국의 전략 경쟁은 코로나 19 이후 심화되는 가운데 중 - 러 간 전략전 연 대 강화, 일본 등 각국의 군사력 증강 및 영향력 확대가 지속되고 있으며, 이러한 안보환경은 코로 나 19 상황과 한반도 비핵화 변수가 접목되어 역내 안보구도의 유동성과 불확실성을 증대시키고 있다.

“미국이 돌아왔다.” 미국은 바이든 행정부 출범 이후 외교를 복원하고 동맹을 복구하여 가치를 앞세우는 미래를 추구할 것이라고 지난 3월 3일 '국가안보전략 중간 지침'10)에서 발표했다. 자유주 의적 제도주의를 추구하겠다는 것은 트럼프 정부의 일방주의와는 비교되지만, 자국의 국익을 최우 선 순위에 놓겠다는 것은 이전 정부의 미국 우선주의에서 크게 벗어나지 못하고 있다. 미국은 중국 과 러시아, 이란 및 북한을 새로운 위협으로 규정하고 '신 봉쇄전략'을 추진하고 있는데 위협 중에 서도 중국을 최대의 위협으로 간주하고 있다. 이런 중국을 억제하기 위해 인도-태평양 지역의 군사 력 증강을 추구하는 ‘태평양 억제 구상’을 위해 2022년 예산에 46.8억 달러를 요청했는데 이는 2021 년에 배정되었던 금액의 두 배를 넘는 액수로 중국에 대한 견제 의도를 여실히 드러내고 있다.11)

중국은 시진핑 집권 이후 세계중심국으로 도약하기 위하여 일대일로(一帶一路)를 통한 주변 국 가들을 중국의 영향권으로 끌어들이고 있다. 이는 표면적으로 상업적 목적으로 볼 수 있지만, 실질 적으로는 군사용으로 사용할 수 있는 목적으로 추진하고 있다. 또한, 2017년 10월 제19차 당대회에 서는 중국몽(中國夢) 실현 로드맵으로 2020년부터 2035년까지 소강(小康) 사회 건설의 기조 아래 사회주의 현대화를 실현하고 2050년까지 '세계 일류 강군 육성'을 통한 사회주의 강국의 전면적 건 설을 목표로 제시하였으며, ‘인류운명공동체'를 기반으로 중국 주도의 새로운 국제질서를 구축하려 는 대외정책을 추진할 것으로 예상된다.12)

10) 국가안보전략지침은 통상 새롭게 등장하는 미 행정부가 외교, 안보, 국방에 관한 방향성을 제시하는 문서로서 이 지침을 근거로 외교전략, 국방전략 등이 작성되게 된다.

11) 서재정(2021. 7.) 바이든 정부의 국가안보전략 - 대북정책과 한반도 평화(http://blog.naver.com/chhioo/222430977727) 
러시아는 푸틴 집권 이후 '강한 러시아의 재건'을 완성하기 위해 국제무대에서 더욱 적극적이고 강력한 대외정책을 추진하고 있다. 2015년 7월에 발표한 '신해양독트린'에서 해군의 작전범주를 대 서양, 인도양, 태평양 등 6 개 해역으로 분류하였는데 이는 러시아가 강한 해군으로 돌아간다는 것 을 의미하는 것이다.13) 다만, 우크라이나 사태 이후 군사계획이 해군에서 육군으로 군비 증가의 무 게 중심이 이동하였지만14) 동북아 지역 내에서 중국과의 전략적 협력을 강화하는 등 아시아-태평 양 지역에서의 군사적 영향력을 지속해서 늘리는 동시에 미국에 대한 견제 의도도 포함되어 있다.

일본은 헌법에 기초한 전수방위 원칙(수동적인 방위전략)을 유지한 가운데 다른 나라를 위협하 는 군사력을 보유하지 않고 비핵 3원칙을 준수하는 것을 방위 기본정책으로 하고 있다. 이를 위해 독자적인 방위력의 양과 질 모든 면에서 강화하고 미·일 동맹 강화를 통해 평화와 안전을 확보하 고 주변국들과의 안보협력을 통해 국제사회에서 영향력을 확대하는 것이다.15) 그리고 북한의 핵 미사일, 중국의 군사력 증강과 급변하는 안보환경에 대응하기 위한 '다차원 통합방위력'을 구축을 통해 작전수행능력 향상을 추진하고 있다.

북한은 2011년 김정은 집권 이후 ‘핵 · 경제 병진노선’을 표방하며, 핵 - 미사일 능력 고도화에 역 량을 집중하여 2017년에는 ‘국가핵무력, 완성을 선언하였다. 2018년 들어 새로운 전략노선으로 ‘경 제건설 총력 집중노선’을 제시하고, 한반도 비핵화 목표를 표방하며 활발한 정상외교를 추진하였으 나, 2019년 하노이 회담 결렬 이후 비핵화 협상 교착국면이 장기화되었다. 2020년 들어 대북 제재 및 코로나 19 로 인한 경제난이 심화되는 상황에서도 자위적 국방력 강화를 명분으로 핵 - 미사일 능력 강화 및 선별적 재래식 전력증강을 통한 작전태세 향상을 도모하고 있다.16) 최근에는 남북통 신선 복원을 통한 관계 개선을 시도하는 한편 미사일 발사를 강행하는 등 핵 및 탄도미사일에 대한 개발을 지속한 가운데 발사 시험을 하는 등 군사적 도발을 감행할 것으로 예상된다.

이처럼 한반도를 둘러싼 동북아 지역의 주변국들은 유리한 안보환경을 조성한 가운데 자국 우선 주의가 심화될 것이며 안보환경의 변화는 지역 내 불안정성을 가중시키는 가운데 역내질서를 변화 시킬 뿐만이 아니라 불확실성을 더욱 확대할 것으로 예상이 된다. 따라서 상비병력을 감축 중인 우 리 군에게는 동북아의 균형과 전투력 유지를 위해 그 어느 때보다도 예비전력 정예화가 중요하다 고 할 수 있다.

\section{1 .2 국방개혁 2.0 과 예비전력 정예화}

우리 군의 국방개혁은 “평화와 번영의 대한민국을 힘으로 뒷받침하는 강한 군대 조기 구현”을 목표로 추진하고 있다. 국방개혁은 참여정부 시절인 2005년에 국방개혁 2020이라는 이름으로 발표

12) 국방부(2020). 2020 국방백서, 서울, p. 11

13) 국방부(2020). 2020 국방백서, 서울, p. 15.

14) The National institute for Studies(2018), p. 170.

15 ) 국방정보본부(2020). 일본 방위백서 2020. 서울, p. 252, 268.

16) 국방부(2020). 2020 국방백서, 서울, p. 19 
되어 추진되었고, 그 후 정권교체와 더불어 몇 차례 수정되었다. 현 정부에서 추진되고 있는 국방개 혁 2.0은 2005년 노무현 정부의 국방정책안을 국방개혁 1.0 으로 간주하고 같은 방향으로 보완하겠 다는 의미를 갖고 있다.

$<$ Table 5> Contents of the past government's defense reform promotion

\begin{tabular}{|c|c|c|c|}
\hline \multirow{2}{*}{ Division } & $\begin{array}{c}\text { Participatory } \\
\text { government }\end{array}$ & $\begin{array}{l}\text { Lee Myungbak } \\
\text { government }\end{array}$ & $\begin{array}{c}\text { Park Geunhye } \\
\text { government }\end{array}$ \\
\hline & Defense Reform 2020 & Defense Reform 307 & $\begin{array}{l}\text { Basic Plan for Defense } \\
\text { Reform }\end{array}$ \\
\hline $\begin{array}{l}\text { Major } \\
\text { contents of } \\
\text { national } \\
\text { defense } \\
\text { reform }\end{array}$ & $\begin{array}{l}\text { - Expanding the civil service } \\
\text { base } \\
\text { - Reorganization of command } \\
\text { structure } \\
\text { - Low cost, high efficiency } \\
\text { defense management } \\
\text { innovation }\end{array}$ & $\begin{array}{l}\text { - Defense Advancement } \\
\text { Promotion Committee } \\
\text { - Active suppression of } \\
\text { North Korea } \\
\text { - Strengthen teamwork }\end{array}$ & $\begin{array}{l}\text { - Strengthening the } \\
\text { capabilities of joint } \\
\text { operations }\end{array}$ \\
\hline $\begin{array}{l}\text { Promotion of } \\
\text { elite reserve } \\
\text { forces }\end{array}$ & $\begin{array}{l}\text { - Supplementing the } \\
\text { organization dedicated to } \\
\text { reserve power } \\
\text { - Improvement of reserve } \\
\text { forces training system }\end{array}$ & $\begin{array}{l}\text { - Guarantee the } \\
\text { effectiveness of partial } \\
\text { mobilization } \\
\text { - Reserve officer elitism } \\
\text { - Science reserve forces } \\
\text { training } \\
\text { - Local reserve forces' } \\
\text { equipment and supplies }\end{array}$ & $\begin{array}{l}\text { - Establishment of a } \\
\text { reserve forces } \\
\text { regionalization } \\
\text { management system } \\
\text { - Introduction of a part- } \\
\text { time service system } \\
\text { - Formalization of regional } \\
\text { reserve forces } \\
\text { - Regional reserve forces } \\
\text { change weapons }\end{array}$ \\
\hline
\end{tabular}

* Source: adapted from Kim, M. S. (2019)

노무현 정부부터 시작된 국방개혁 추진내용에서 예비전력 정예화 추진을 평가해 보면 <Table $5>$ 와 같은데 동원위주부대 부대구조 발전 및 예비군훈련 위주의 추진이었으며 상비전력과 정예화 추세와 비교 시 미미한 수준이며 지역예비군과 관련해서는 박근혜 정부부터 본격적으로 지역예비 군 정예화를 추진하였으나 일부 장비 - 물자만 확보 및 교체하는 등 계획대비 시행에 있어 다소 부 족하였다(Kim, M. S., 2019). 국방개혁 2.0에서 예비전력 발전과 관련해서 제시한 사항은 예비전력 내실화, 즉 선택과 집중을 통해 핵심전력 중심의 전력을 강화하는 것으로 첫째, 핵심 동원전력(동원 사단, 동원보충대대) 우선 정예화 둘째, 예비군 훈련체계 개선(과학화 예비군훈련장 구축) 및 비상 근 예비역제도 도입 셋째, 예비전력 예산을 국방예산의 $0.3 \%$ 에서 $1 \%$ 이상 수준까지 단계적으로 증 액을 중점에 두고 있다.17) 또한, 육군본부에서는 예비전력 정예화를 위해 미래 작전환경, 가용자원 등을 고려한 예비군 임무에 부합된 예비군 적정 규모와 편성 최적화를 추진하고 있는데 주요 내용 17) 국방부(2019). 국방개혁 2.0. 서울, p. 31. 
은 지역예비군 운용개념 재정립과 예비군 자원 감소와 연계한 예비군부대 단계별 조정, 예비군부대 통·폐합과 연계한 예비전력군무원 정원 조정 등이다.18)

이러한 추진내용을 볼 때 과거 국방개혁에 비해 다소 실질적인 목표와 방향을 제시하고 있지만, 법령, 예산 등 관련된 내용을 면밀하게 고려하여 추진하지 않으면 지난 국방개혁처럼 예비전력 그 중에서도 중요도가 가장 낮은 지역예비군 정예화는 또다시 계획으로만 그칠 수 있기에 보다 주도 면밀한 계획 수립 및 추진이 요구된다. 또한, 주요 대외국가의 국방개혁과 예비전력 정예화 사례들 을 모방한 정예화 추진도 요구된다. 미국의 경우 1920년 국가방위법을 제정하여 정규군과 주방위 군, 연방예비군을 포함하는 일원화된 조직체계를 갖추었으며, 1973년 모병제 전환에 따라 총체 전 력정책을 도입하여 이라크-아프간전쟁 등에 예비군이 투입되어 성공적으로 임무를 수행하는 등 총체전력의 구성요소로 자리매김할 수 있었다(Shin \& Jung, 2016). 싱가포르는 현역 복무 후 10년 간 예비군에 편성되고 보직도 고정된 상태에서 1 년에 약 40 일 정도 강도 높은 훈련을 실시하며, 현 역과 동일한 장비 - 물자를 확보하고 있다. 사회에서 받는 동일한 보수와 현역과 같은 인센티브를 제공받고 감세 혜택, 각종 연회, 스포츠 활동, 의료지원 등 예비군에 대한 복지 제도가 우수하다 (Koo \& Park, 2019, pp. 388-389). 외국의 안보환경이 우리의 상황과 다르지만, 미국의 사례에서 보 듯이 예비전력을 총체 전력으로 구성한 국방개혁과 싱가포르처럼 강한 예비군훈련, 장비 - 물자의 현대화, 각종 복지혜택 제공 등은 예비전력 정예화를 위해 노력하고 있는 우리에게 시사하는 바가 크다고 할 수 있다.

\section{1 .3 사회적 환경변화}

‘대한민국이 소멸한다.' 데이빗 콜먼(David Coleman) 옥스퍼드대 교수는 저출산으로 인한 인구 소멸 국가1호가 대한민국이 될 것이라는 충격적인 발표를 하였다. 실제로 출산율을 이대로 방치하 면 2100년의 인구는 2천만 명으로 줄어들고 2300년이 되면 사실상 소멸 단계에 들어가게 될 것이라 고 예견하고 있다.19) 우리는 한강의 기적이라고 불리는 눈부신 경제성장을 통해서 선진국의 지위 에까지 이르렀다. 그러나 급격한 경제발전은 저출산 및 고령화로 인구구조가 변화하였고 도시지역 으로 인구의 집중-심화- 밀집되는 등 도시화 현상이 가속화되어 거대도시들이 탄생을 수반하였 다. 이로 인한 지역예비군 운영과 관련되는 영향요인을 분석해 보면 다음과 같다.

인구의 증감은 국가의 운명을 좌우하는 중요한 문제로 국방에 기여하는 아주 중요한 요소이다. 인구의 변화와 예비전력과의 관계는 경제성장 $\rightarrow$ 인식변화 출산감소 $\rightarrow$ 가용 상비전력자원 부족 예비군 부족 순의 사이클로 설명될 수 있다. ' 15 년 이후 저출산 기조가 악화되며,'20년 합계출산율 0.84 명을 기록하였는데 이는 UN 198 개국 중 2 년 연속 최하위이며 $\mathrm{OECD}$ 회원국 중 유일하게 합계

18) 육군본부(2019). 예비전력 비전 2030. 계룡, p. 요약-19-4.

19) KBS뉴스(2015. 4. 6.). 인구 소멸 국가 1호 대한민국, 어떻게 살아남을 것인가? https://news.kbs.co.kr/news/view.do? ncd $=3050975$ 
출산율이 1 미만을 기록하는 국가가 되었다. 문제는 '20년 처음으로 인구 데드크로스를 기록하여 인구 자연감소가 시작되었다는 것이다. 출생아 수는 ' 02 년 이후 15 년간 유지해오던 40만 명대가 무 너진 뒤 3년 만에 30만 명을 밑돌며 '20년 출생아 수는 27.2만 명을 기록하였다.20) <Table 6> 20대 남자 인구는 매년 2 5\% 자연감소가 예상되며, 이에 따라 <Table $7>$ 과 같이 예비군 자원도 계속 해서 감소할 것으로 전망된다.

$<$ Table 6> Estimation of male population fluctuations in their 20s21)

\begin{tabular}{c|c|c|c|c|c|c}
\hline Division & 2020 & 2022 & 2025 & 2028 & 2030 & 2035 \\
\hline \hline \# of people & $3,703,732$ & $3,548,195$ & $3,094,403$ & $2,690,379$ & $2,471,743$ & $2,302,636$ \\
\hline Decrease rate (\%) & - & 4.2 & 12.8 & 15.7 & 8.2 & 6.9 \\
\hline
\end{tabular}

$<$ Table 7> Future reserve forces resource change trend22)

\begin{tabular}{c|c|c|c|c|c}
\hline Division & 2020 & 2022 & 2025 & 2028 & 2030 \\
\hline \hline $\begin{array}{c}\text { \# of people } \\
\text { ten thousand) }\end{array}$ & 268.6 & 259.1 & 239.1 & 224.3 & 217.7 \\
\hline Decrease rate (\%) & - & 3.6 & 7.7 & 6.2 & 2.9 \\
\hline
\end{tabular}

그러나 정부의 출산율 추계보다 더 비판적인 시각도 존대한다. 출산율이 높은 지방 청년이 그대 로 지방에 잔류한다면 추계대로 되겠지만 이들이 끊임없이 출산율이 낮은 서울로의 진입을 꿈꾼다 면 지금의 추계보다 더 낮아지리라는 것이다. 지방에서 $2 \sim 3$ 명을 낳을 것으로 예상하는 청년 인구 가 실제 거주지를 서울로 옮기면 1 명도 채 낳지 않게 되는데 인구추계에서 이런 현실이 배제되었다 는 것이다.23) 출산율 저하는 가용 상비전력자원 부족으로 이어져 대규모 예비전력 유지에 제한요 소로 작용할 것으로 예상되며 제한요소를 극복하기 위해 예비전력 정예화가 추진되어야 한다.

또 다른 영향요인은 도시지역으로 인구의 집중·심화·밀집되는 현상이다. 수도권으로의 쏠림 현상이 지속되어 '20년 처음으로 수도권 인구가 비수도권 인구를 추월하였고 소멸고위험지역이 빠 르게 증가하여 전국 228 개 시 · 군 · 구 중 105 개가(46\%) 소멸위험지역에 해당되고 있다.24)

$<$ Table 8>과 같이 대도시 지역은 가용자원이 많아 지역예비군 편성 - 운용에 유리한 반면 농 어촌 지역의 가용자원은 턱없이 부족해 지역예비군 편성이 제한되는 실정이다. 출산율 감소 추세와

20) 관계부처 합동(2021). 인구구조 변화 영향과 대응 방향-총론: 인구구조 변화 대응전략. 세종, p. 1.

21) 통계청(2020). 20대 남자 인구 변동 추계. 대전.

22) 육군본부(2018). 예비전력 비전 2030. 계룡, p. 3장-14-4.

23) 전영수(2018). 한국이 소멸한다. 서울: 비지니스북스.

24) 관계부처 합동(2021). 인구구조 변화 영향과 대응 방향-총론: 인구구조 변화 대응전략. 세종, p. 2. 
지역방위작전이 시 · 군 - 구별 이루어지는 것을 고려할 때 미래의 지역방위작전 수행에 있어서 농 어촌 지역은 자원이 절대적으로 부족하여 작전 수행에 차질이 발생할 것이며 반면 도시지역은 가 용자원이 충분해 작전수행간 제한사항이 없을 것으로 예상된다. 이에 따라서 도시지역과 농 - 어촌 지역의 자원을 효율적으로 운용할 수 있는 대책과 시·군 · 구와 유기적인 협조를 통한 작전지속지 원 방안에 대한 검토가 필요하다.

$<$ Table $8>$ Status of male population in their 20s (20-29 years old) by region25)

\begin{tabular}{c|c|c|c|c|c|c}
\hline \multirow{2}{*}{ Division } & \multicolumn{3}{|c|}{ Metropolitan city } & \multicolumn{3}{c}{ Rural and fishing villages } \\
\cline { 2 - 7 } & $\begin{array}{c}\text { Gangnam-gu, } \\
\text { Seoul }\end{array}$ & $\begin{array}{c}\text { Yeonsu-gu, } \\
\text { Incheon }\end{array}$ & $\begin{array}{c}\text { Yuseong-gu, } \\
\text { Daejeon }\end{array}$ & $\begin{array}{c}\text { Cheongsong-gun, } \\
\text { Gyeongsangbuk }\end{array}$ & $\begin{array}{c}\text { Jinan-gun, } \\
\text { Jeollabuk }\end{array}$ & $\begin{array}{c}\text { Sinan-gun, } \\
\text { Jeollanam }\end{array}$ \\
\hline \hline \#of people & 32,778 & 28,094 & 35,879 & 922 & 977 & 1,533 \\
\hline
\end{tabular}

\section{2 미래 지역예비군 운영의 최적화 방안}

\subsection{1 운영체계 재정립}

\subsubsection{1 지역예비군 임무 재정립}

앞에서 언급한 바와 같이 한반도의 대 - 내외 안보환경은 급변하고 있으며, 이에 따라 미래 안보 환경 및 사회변화를 고려하여 기존의 지역예비군의 임무와 역할을 재판단하고 새로운 임무와 역할 에 맞추어 정예화를 추진해야 한다. 군사 및 비군사적 위협과 사회환경의 변화에 맞게 현재의 예비 군 임무를 재검토하여 전 - 평시 군사적 및 비군사적 임무, 국가이익지원 등으로 재정립하며 예비 군의 역할은 국가안보태세 확립과 지역방위 작전 수행 이외에도 국민 안보의식 고취의 매개체, 국 가이익 지원 등으로 역할과 수행의 범위를 확대해야 한다. '80년 이후 지속 유지되고 있는 현재의 예비군 임무를 미래 안보환경 및 사회변화에 맞게 재설정하면 다음과 같다.

$<$ Table 9> Reserve forces' mission (improvement plan)

1. Prepare for mobilization during wartime, peacetime, or national emergency

2. Non-military support (national disasters: e.g., casualties, natural disasters)

3. Participate in international peace activities and strategies

4. Support other activities to protect the lives and property of the people

미래의 예비군은 상비군과 함께 총체전력의 일부로서 전시 대등한 수준의 전투력을 발휘할 수 있도록 평시에 준비되어 있어야 한다. 따라서 미래 예비군의 임무는 첫째, 전 - 평시 군사적 위협을

25) 통계청(2020). 연령 및 성별 인구-읍면동. 대전. 
고려하여 현역부대의 증 - 창설 및 작전 수행을 위한 동원과 평시 테러 등 위기 발생 시 지역방위를 위한 동원 임무를 수행하며 둘째, 국가적 재난(대형 인명사고, 자연재해) 발생 시 복구에 많은 인력 과 기간이 소요되는 점을 고려하여 비군사적 위기 상황시 예비군을 지원하는 것을 반영하는 것이 적절하겠다. 셋째, 예비군의 활동 영역을 확대하여 국제사회의 활동과 작전에 참가할 수 있도록 역 할을 확대하며 마지막으로 예상하지 못한 상황에서 국민의 생명과 재산을 보호해야 하는 임무를 포괄적 안보시대에 예비군의 임무에 포함한다. 국가안보태세 확립이라는 기본적인 역할 이외에도 비군사적 지원과 국가이익과 국민을 위한 제반 활동을 수행하여 예비군의 영역을 확대함으로써 국 민 안보의식 고취의 매개체 역할을 수행할 수 있기 때문이다.

\subsubsection{2 지역예비군 조직·편성 최적화}

지역예비군부대는 국방개혁 2.0 추진에 따른 현역부대 개편, 상비병력 감축, 예비군부대 통 - 폐 합 등의 작전환경 변화와 사회적 환경변화(인구절벽에 따른 예비군 자원감소, 4 차 산업 등)에 직면 해 있어 이에 맞는 지역예비군의 조직 - 편성 최적화가 요구된다. 예비군 운용은 작전환경의 변화, 예비군 가용자원 등을 고려하여 읍·면 - 동 단위 운용개념에서 지역방위사단의 관할지역을 고려 하여 광역시 - 도 단위 운용26) 영역을 확대하고 목진지 및 검문소 운용 등 배치 - 운용하는 것을 기 동타격과 핵심시설 방호개념으로 병력 운용을 조정하며 지역예비군 소요는 예비군 자원수, 지역 내 핵심방호시설, 관할지역 특징 등을 고려하여 수임군부대별 지역 단위 보유기준을 마련해야 한다. 지역예비군 편성은 앞에서 언급한 변화들을 고려하여 단계적으로 예비군부대 개편을 추진하여야 한다.

Step 1('25년) 지역방위사단 개편과 연계하여 기존 읍 - 면 - 동 단위 중대에서 보병여단 단위 대 대 편성으로 전환하여 추진하며 예비군부대 통 - 폐합, 지역방위사단 개편과 연계하여 여단별 1 개 예비군대대를 창설 및 운영을 추진하고 여단의 예속부대로 편성하여 임무를 수행한다. 예비군대대 와 보병대대는 협조관계이며 예비군대대에는 대대본부, 예비군중대, 기동대, 재난지원 중대로 편성 한다. 예비군중대는 통 - 폐합과 예비군중대장 정년 등을 고려하여 수개 중대로 편성하여 운용하며 자원감소를 고려하여 운용해야겠다. Step 2('30년) 예비군 방위여단을 창설하여 기존 예비군대대를 예비군 방위대대로 개편하여 예비군 방위여단의 편제 부대로 반영하며 예비군 방위대대에는 대대 본부와 기동대, 재난지원 중대로 편성하여 운용한다. 기동대는 3개 중대를 편성하여 운용하며 자원 수가 많을 경우에 수개 중대로 편성하여 운용한다. 미래 지역예비군 단계 편성을 도식화하면 $<$ Figure $2>$ 와 같다.

26) 후방지역 지역방위사단은 관할지역을 2 개 이상의 광역시 - 도로 되어 있으며 도의 가용자원은 광역시에 비해 상대적으로 부족해 작전의 융통성을 위해 지역예비군은 수임군부대장 관할지역에서 운용이 가능하도록 해야 한다. 


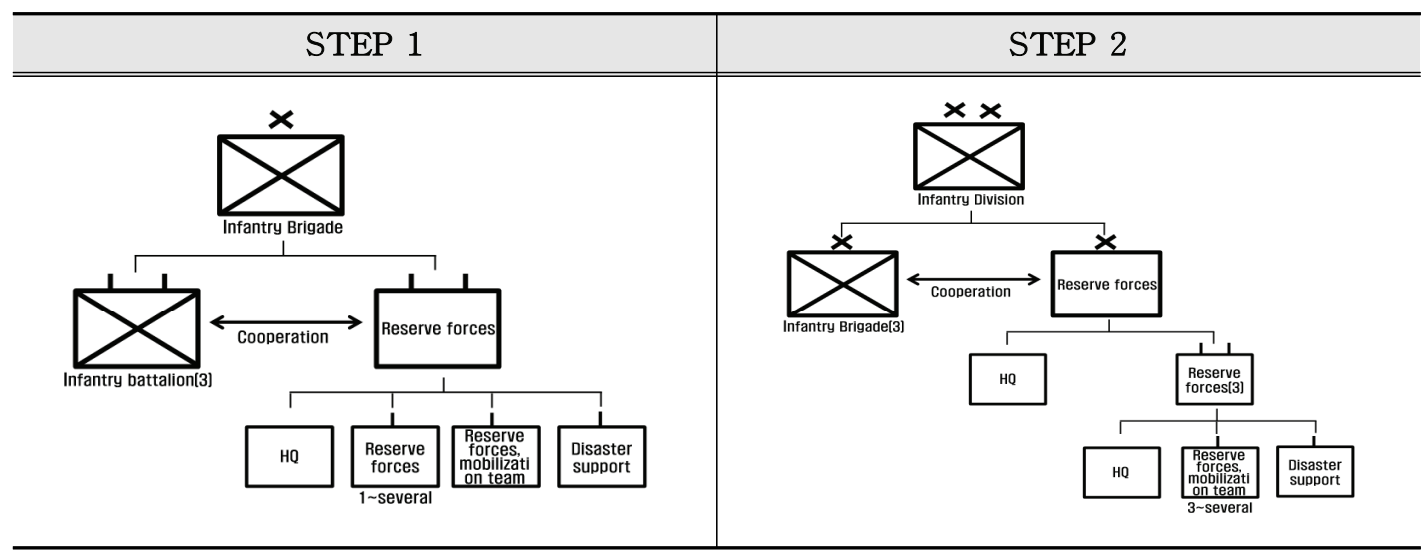

$<$ Figure 2> Organizing the future regional reserve forces stage

보병대대는 3 6개의 시 • 군 · 구 지역을 담당하여 후방지역 상황발생시 통합방위작전을 수행하 며 예비군대대 및 예비군 방위대대는 평시 자원관리, 교육훈련, 재난복구 등 비전통 위협에 대응하 며 상황 발생 시 지역방위대대를 증원, 중요시설 방호 및 경계지원 등의 임무를 수행해야겠다.

지역예비군부대를 싸울 수 있는 조직으로 개편하기 위해 주요직위자에 대한 보강이 선행되어야 한다. 농 - 어촌의 경우 간부 자원이 적어 보직률이 낮으며 희소특기 병사도 자원이 부족한 실정이 다. 부족한 주요 직위자 보직율 향상을 위해서 첫째, 예비전력관리군무원 직급을 다단계하여 정원 을 늘리고 이를 대대 및 지역대 참모, 소대장으로 활용하는 방안이다. 둘째, 현재 국방부에서 추진 중인 비상근 예비군제도와 연계하여 주요 직위자를 선발하여 보직율을 향상시켜 부족한 주요 직위 자를 해소하는 것이다. 여단 - 대대에 근무하는 예비군(정작과, 지원과, 동원과, 본부중대 각 1명)27) 은 장기(180일)로 선발하고 예비군중대 근무하는 예비군(부중대장 또는 소대장)은 단기(30일)로 선 발해서 운용한다. 인원은 Step 1에는 2,362명(대대별 4명, 예비군중대별 1명)으로 예산은 53.4억이 소요되며 Step 2에는 556명(여단 - 대대별 4명, 예비군중대별 1명)으로 예산은 48.5억 소요될 것으 로 예상된다.28) 셋째, 중대본부29) 희소특기 병사 보직률을 높이기 위해 희소특기를 유사특기로 지 정하는 것이다. 예를 들어 병기와 보급, 행정과 통신을 유사특기로 묶어 지정할 수 있도록 하는 것 인데 이는 지침 개정 시 가능하므로 검토할 필요가 있다.

또한, 지역예비군부대의 전투력 발휘를 위해서는 기동대의 정예화도 필요하다. 지역예비군부대

27) 지역예비군 여단·대대의 참모부를 지휘부, 정작과, 지원과, 동원과로 판단하였다.

28) Step 1에는 지역방위사단(13개)과 '24년 지역예비군부대(2,290개) 부대 수를 고려해서 소요인원을 판단하였으며 Step 2 에는 지역방위사단(13개)과 ' 30 년 지역예비군부대는(400개) 기동대(수도권 및 대도시 5 개 이상, 지방 3 개)와 재난지원중 대를 고려해서 판단하였다.

29 ) 지역예비군 중대본부 병사는 6 개 특기 16 명으로 편성되어 있다(통신 2 , 병기 2 , 보급 2, 의무 2, 운전 6). 육군본부 『2020년 예비군 조직편성 지시』. 2020. pp.29-4. 
에서 차지하는 기동대의 역할과 중요성을 고려하여 전투임무 수행의 핵심전력으로 만들어야 한다. 일부 부대의 경우 자원부족을 이유로 기동대를 우선 해체하는데 연차를 7 8년차까지 확대하고 동 원배정지역 제외 등 기동대를 유지하기 위해 노력해야 하며 중요시설이 많은 지역은 기동대를 추 가 편성하는 등 자원관리만 하는 예비군부대에서 싸워 이길 수 있는 예비군부대로 성장시켜야 한 다. 장비는 현역과 동일하게 우선 보급하여 임무수행 여건을 보장해 주되 현재 추진하고 있는 워리 어 플랫폼을 기동대에 적용하는 등 미래에 대비하는 조직으로 만들어야 한다. 지역예비군의 정예화 를 위해서는 예비군 조직·편성 최적화가 필요하며 교육훈련, 무기·장비 현대화, 예비전력 예산 확보 등도 중요하지만 이런 것들은 조직 - 편성 최적화를 통해 이루어지기에 보다 앞서서 명확하게 설정하고 운영하는 것이 중요할 것이다.

\subsection{2 지역예비군 교육훈련}

국방개혁 2.0의 핵심은 상비병력을 감축하고 그 공백을 정예화된 예비전력으로 대체한다는 것이 다. 상비병력의 감축과 복무기간 단축은 예비전력의 전투력에도 영향을 미치기 때문에 예비전력의 정예화를 위해서는 교육훈련이 그 어느 때 보다 중요하다고 할 수 있다. 현재 우리 군은 국방개혁 2.0과 연계하여 지역예비군 훈련체계 개선을 위해 과학과 예비군훈련장을 권역화하여 ' 24 년까지 40 개소를 설치 중이다. 후방지역에서 지역예비군의 중요성을 인식하여 주력군으로 편성하고 효과적 으로 운용하여 전투에서 승리할 수 있는 전력으로 조직하기 위해서는 현재 시행 중인 지역예비군 훈련에 대한 획기적인 발상이 요구되며 전투력을 발휘할 수 있는 수준으로 만들기 위한 교육훈련 체계를 검토해 보면 다음과 같다.

첫째, 임무수행이 가능한 수준의 훈련 기간에 대한 재검토이다. 훈련 기간에 대한 검토는 예비군 의 숙련도 망각주기 등을 고려하여 훈련 반복주기를 고려할 수 있다. 일반적으로 병사가 병과별 개 인 임무수행능력을 숙달하는데 소요되는 시간은 대략 $11 \sim 13$ 개월이다(Table 10).

$<$ Table 10> Period of mastering individual tasks for each military occupational specialty30)

\begin{tabular}{c|c|c|c|c|c}
\hline Division & Infantry & Artillery & Armored & Communication & Maintenance \\
\hline \hline Min. period & 11 months & 12 months & 13 months & 11 months & 13 months \\
\hline
\end{tabular}

훈련을 통해 습득된 전투기술을 얼마나 잘 유지하느냐가 예비전력 전투력에 직접적인 영향을 미 치게 되는데 사용하지 않는 전투기술은 망각되기 쉬우며 그 기간이 증가할수록 늘어난다. 연구에 의하면 훈련 후 6 8개월에 비해 훈련 직후 2 개월 기간 내에 더 많이 감소한다. 즉, 전투기술은 전 역 후 2 개월 이내에 급격히 망각되며 2개월 이후에는 임무수행이 제한된다. 미 공군 예비군 병사를 대상으로 한 연구에서는 전역 후 18 24개월 지난 시점에 53\%의 병사들이 숙련도를 유지하였다는 
것을 제시하고 있다.31) 이 두 결과를 통해서 알 수 있는 것은 전역과 동시에 전투기술은 급격하게 망각되므로 망각주기를 고려한 훈련주기 편성이 필요하다는 것이다. 현재 지역예비군은 연 1회 기 본훈련(8시간)과 연 2회 작계훈련(6시간)을 하고 있다. 연구결과의 망각주기 등을 고려 시 지역예 비군 훈련 주기는 최소 2 개월 단위로 기본훈련과 작계훈련을 시행하여 전투기술을 유지해야 한다. 예비군훈련시간을 늘리는 것은 국민적 공감대 형성이 필요하므로 이에 대한 사전 충분한 연구가 필요하다.

둘째, 훈련방법과 훈련과제에 대한 개선이다. 기본훈련은 사격, 정신교육, 기타과제로 구성된다. 사격시 지급되는 총기는 안전문제로 별도의 사격용 총기를 고정으로 운용하고 있으며 훈련 간 지 급되는 총기도 훈련용 총기로 상황발생 시 본인에게 지급되는 총기가 아니다. 현역 시절 다루던 총 기와 상이하고(현역 $\mathrm{K}-2$, 예비역 M16) 영점을 획득한 총기도 아니기에 상황발생 시 동원예비군과 는 다르게 바로 임무수행을 해야하는 지역예비군의 특성과 전투력 유지 측면을 고려했을 때 훈련 시에도 동일한 총기를 지급하는 것을 검토할 필요가 있다. 기타과제는 수임군부대의 특성과 임무에 맞는 훈련으로 구성하되 화생방, 구급법과 같이 재해재난 - 테러 등에 대비한 과제를 선정하고 팀 단위로 상황발생시에 임무수행하는 과제를 포함해야 하며 4차 산업과 연계한 훈련(VR, 마일즈 장 비 등)도 발전시켜야겠다. 작계훈련은 작계지역 또는 유사지역에서 실시하게 되어 있으나 작전지역 의 도시화로 현실적으로 해당 지역에서의 훈련은 제한이 되고 있으며 지역예비군 운용(목진지, 검 문소 $\rightarrow$ 기동타격) 개념변화 등을 고려하여 작계지역이 아닌 예비군훈련대로 훈련 장소를 변경하는 것을 검토해야 한다. $\mathrm{VR} \cdot \mathrm{AR}$ 훈련장을 구성하여 작계지역 상황하 소대 또는 분대단위 다양한 상 황조치 훈련을 숙달할 수 있도록 구성하고 대항군 운용 등 실전적인 훈련을 할 수 하는 방안을 검 토해야 한다.

또한, 예비군 인센티브제에 대해서도 검토가 필요하다. 인센티브 제도는 예비군 훈련 우수자에 대해 조기 퇴소를 시행하고 있는데 훈련에 대한 자발적 참여를 유도한다는 측면에서 긍정적이나 퇴소 이후 남은 예비군들의 훈련참여에 대한 분위기와 퇴소 이후 남은 시간은 새로운 과제 훈련의 제한, 그리고 퇴소 인원 발생으로 소대 - 분대 단위 전술과제 숙달 시간의 제한 등을 고려해야 한다. 인센티브 제도의 긍정적인 면을 고려 시 제도는 유지하되 조기 퇴소 이외의 다른 대안이 필요하다. 예를 들어 지역상품권 등을 인센티브로 제시한다면 훈련 참여에 대한 긍정적 효과와 동시에 지역 경제 활성화에도 조금이나마 도움이 될 수 있다고 생각한다.

마지막으로, 지역예비군 전투력 향상과 유지를 위한 지휘통제훈련 개선이다. 지역방위작전을 위 한 전투력 향상은 모두 지역예비군에게만 초점이 맞춰져 있다. 물론 지역방위작전에서 지역예비군 이 차지하는 비중은 높지만 지역예비군을 운용하기 위해서는 적절한 지휘통제가 있어야지만 가능 하다. 민 - 관 - 군 - 경 통합방위 능력의 배양을 위해 주요 부대훈련 시 전 작전요소를 통합하여 훈 련하지만, 대대별 일부 중점작전지역에 해당되는 예비군부대만 참가할 뿐 나머지 부대는 상황만 유

31) 한국전략문제연구소(2005). 2005년 육군전투실험 정보기술을 활용한 전투실험 방법론 연구. 서울, pp. 297 299. 
지하고 있으며 대대의 지휘통제는 미미한 실정이다. 지역방위작전은 전 - 평시에 발생하나 전시와 같은 상황을 상정한 지휘통제 훈련은 미실시하고 있다. 대대 동원훈련과 연계한 작계훈련을 실시하 여 대대의 능력으로 지휘통제가 가능한지 검증하고 미흡한 분야에 대해서는 보완을 하는 등 실질 적으로 전시에 싸워 이길 수 있는 지역방위작전을 준비해야 한다.

이상과 같이 위에서 제시한 개선해야 할 지역예비군 훈련을 정리해 보면 다음과 같다.

$<$ Table 11> Improvement of regional reserve forces training

\begin{tabular}{c|c|c}
\hline Division & Basic training & Fieldwork training \\
\hline \hline Time & 16 hours (8 hours in the first half of year) & 24 hours (6 hours in the quarter) \\
\hline Place & \multicolumn{2}{|c}{ Scientific training ground, Fieldwork } \\
\hline Task & $\begin{array}{c}\text { Shooting, mental education, tactical tasks, } \\
\text { terrorist and disaster response tasks, etc. }\end{array}$ & \multicolumn{2}{c}{ Tactical task } \\
\hline $\begin{array}{c}\text { Relative } \\
\text { height }\end{array}$ & - & $\begin{array}{c}\text { Implementation in connection with major } \\
\text { training and mobilization training }\end{array}$ \\
\hline
\end{tabular}

기본훈련은 반기 단위 1 일 8 시간씩 훈련하며 사격과 정신교육은 각 2 시간씩 시행하고 전반기에 는 전술과제(4시간)를 후반기에는 테러 - 재난 대응과제(4시간)를 훈련하는 것이다. 작계훈련은 분 기단위 1 회(6시간) 훈련하되 기본훈련과 연계하여 전·후반기 기본훈련 후 작계훈련을 실시하고 대부대급 훈련과 대대 동원훈련 시에 작계훈련을 각 1 회씩 훈련하는 것이다. 예비군훈련 시간의 증 가는 국민정서를 고려할 때, 매우 부정적으로 보일 수 있으므로 신중한 접근이 필요한데 외국의 예 비군훈련 시간을 참고하여 접근하는 방식이 필요하다.

주요 국가의 예비군훈련 시간을 살펴보면, 미국은 지정(선발)예비군은 연간 12 주, 연 192시간 집 체교육을 실시하며 연간 $14 \sim 39$ 일 이하의 기간 동안 현역으로 훈련에 참가한다. 개인준비예비군은 연간 30 일 이하의 훈련에 참가하며, 미복무 주방위군은 연 1 회 소집점검 훈련을 실시하고 있다. 이 스라엘 예비군 교육은 예비군 사단에서 1 주일 기본훈련 후 현역부대에 배치되어 현역과 함께 임무 를 수행한다. 예비군 소집훈련은 3년 동원 계급별로 매년 25일에서 84일까지 실시하며(전투병 25 일, 전투 지원병 54일, 부사관 70 일, 장교 84 일) 모든 예비군은 3 년에 1 회 30 일까지 동원지정된 예비 군 대대에 의한 작전운용부대에 근무 또는 기타 소집부대에서 근무한다. 또한, 매년 1회 1주(5일) 대대단위 동원훈련을 한다. 싱가포르는 현역 복무 후 10 년간 예비군에 편성되고 1 년에 약 40 일 정 도 강도 높은 훈련을 실시한다.32) 역종에 따라서 예비군훈련 시간이 상이하지만, 앞에서 살펴본 주 요 국가들은 전투력 유지를 위해 연간 30일 이상의 예비군훈련을 시행하고 있으며 강도 높은 훈련 을 통해 우수한 예비군을 육성하고 있다. 이와 비교해 우리의 예비군 교육시간은 턱없이 부족한 실 정이다. 북한과 대치하고 있는 안보환경과 총체전력에서 예비전력이 차지하는 비중이 높아지는 현

32) 국방부 동원기확관실(2017). 2017년 외국의 예비군 및 동원제도. 서울, p. 42, 206 208, 255 
실을 고려시 예비군 교육에 대한 성과 제고를 위해 질적 - 양적 향상을 위한 방안 마련이 시급하다. 이해와 설득을 통해 예비군훈련 시간을 확대하여 싸워 이길 수 있는 예비군을 육성하도록 검토할 필요가 있다.

\subsection{3 작전지속지원체계 발전}

\subsubsection{1 장비 및 물자 개선}

지난 20여 년간 지역예비군 무기 - 장비 - 물자 - 시설은 많은 발전이 있었지만, 아직도 매우 열악 한 상황이다. 장비 및 물자의 수준을 현역 수준으로 올리고 작전소요 대비 $100 \%$ 이상 확보를 해야 하며 아울러 장비 - 물자 구매체계, 유지 - 정비 등에 대한 시스템에 대한 보완도 필요하다. 지역예 비군 운영 최적화를 위해서는 장비 및 물자 개선이 핵심이며 목표 수준에 도달하지 못할 경우 우리 군이 추구하는 국방개혁에 도달하지 못할 수 있기 때문이다. 이에 따른 지역예비군 장비 및 물자 개선 보완사항을 살펴보면 다음과 같다.

첫째, 지역예비군 전투준비태세 유지를 위한 장비 - 물자 현대화가 필요하다. 예비군 무기는 1968 년 창설 이후부터 지금까지 현역에서 퇴역하는 장비를 활용하여 전력화를 추진해 왔으며 30년 이 상의 경과된 노후 장비 및 물자를 다수 보유하고 있고 정비 인원 부족으로 관리에 대한 부담이 가 중되고 있다. 또한, 현역 시절 접해보지 못한 구형장비로 예비군훈련 시 숙달시간이 추가로 소요된 다. 이에 따라서 전투력 발휘 측면에서 장비 - 물자의 현대화가 요구되므로 예비군중대는 전투 효 율성을 고려하여 개인화기, 조준경 등의 장비 현대화를 추진하고 기동대는 현재 육군에서 추진하고 있는 워리어 플랫폼을 적용하여 미래 작전환경에 대비해야 한다. 통신장비는 통합방위작전과, 테러 국가재난 등 비군사적 위협 시 효과적인 지휘통제를 위한 무전기의 보강도 필요한데 현재 육군본 부에서 검토 중인 국가 재난 안전통신망을 빠르게 구축하는 등 전투준비태세 유지를 위해 노력해 야 한다.

둘째, 지역예비군 장비 - 물자 구매방법을 개선해야 한다. 현재 장비는 수임군부대에서 물자는 군수사에서 계약 후 위탁조달로 구매하고 있는데 수임군부대 실무자는 장비 계약에 대한 경험이 없어 조달까지 오랜 시간이 소요되고 있다. 또한, 수임군부대별 계약하는 업체가 상이하여 가격 차 이가 발생하는 등의 문제점이 발생하고 있어 개선이 필요하다. 지역예비군 장비 - 물자를 군수사에 서 계약하여 수임군부대별 위탁조달하는 체계로 변경해야 한다. 구매 장비 중 전투에 긴요한 장비 는 현역 시절과 동일한 장비를 구매하여 지역예비군 동원 시 별도 교육 없이 즉시 사용이 가능하도 록 해야 한다. 아울러 지금껏 육성지원예산을 활용하여 구매한 장비도 정비 및 관리가 가능하도록 지침 개선의 필요성이 제기된다. 


\subsubsection{2 급식지원체계 구축}

지역예비군에 대한 급식은 작전지역을 관할하는 지방자치단체장(통합방위지원본부)이 지원하고, 지방자치단체를 통한 급식 지원이 제한될 경우에는 수임군부대장 책임하 군 작전부대에서 지원하 고 추후 해당 지방자치단체와 정산토록 명시되어 있다.33) 지방자치단체는 읍 - 면 - 동 방위지원본 부에서 지역내 식당과 협의각서를 체결하여 동원된 예비군에 대한 급식을 지원하고 있다. '96년 강 릉지역 무장공비 침투사건 이후 미흡사항을 참고하여 급식 지원 계획을 보완하였지만 25년간 시행 되지 않아 이에 대한 검증과 절차 숙달을 통해 완벽한 급식지원체계를 구축해야겠다. 급식과 관련 하여 보완 및 발전시킬 사항은 다음과 같다.

첫째, 읍·면·동별 지원 능력을 고려하여 급식 계획을 수립하고 식당과 합의각서를 체결해야 한다. 농 - 어촌의 식당은 도시지역에 비해 규모도 작고 상황발생 시 많은 인원에 대한 급식 지원을 위한 부식준비도 제한이 되기에 합의각서 체결 전 지원 능력을 반드시 확인해야 하며 전시에는 식 당 미운용 상황을 상정하여 급식 지원대책을 강구해야 한다. 전방군단의 주민철수지역 예비군들에 대한 군 급식 시스템도 점검해야한다. 현역부대의 급식 취사트레일러로 추가 급식 능력이 제한되기 에 경기 북부에 있는 대형 급식업체들을 동원하는 방법과 군 급식지원대를 편성 - 운용해서 급식을 지원하는 방법들을 검토해야 한다.

둘째, 시스템에 의한 급식이 지원되어야 한다. '96년 강릉지역 무장공비 침투사건 시 급식지원이 제대로 이루어지지 않아 작전을 지휘해야 하는 예비군중대장이 급식지원에 더 많은 노력을 낭비하 는 사례들이 있었다. 이를 방지하기 위해 급식지원 업체, 지원차량, 차량운전 및 선탑 등 계획이 구 체화 되어 있어야 하며 훈련 시 숙달을 통해 미흡사항을 보완해야 한다. 작계훈련 시 협약식당에서 식사 후 훈련을 하고 있는데 반대로 작계지역에 먼저 투입후 급식지원 시스템 매뉴얼대로 시행이 되는지 점검을 할 필요가 있다. 급식지원은 지방자치단체의 업무로 담당자와 함께 급식지원 체계를 점검하고 미흡사항을 보완해야 한다.

마지막으로 지역예비군 급식결산 시스템을 갖추어야 한다. 예비군 동원응소, 하령결과 확인, 결 산 과정이 시스템에 의해 이루어지고 일보작성, 사후 제급식 병력보고서 작성도 체계적으로 이루어 지도록 해야한다. '96년 강릉 잠수함 침투 사건시 현역 급식수준에 못 미치고 일부는 예비군들에게 식사 대신 빵이나 우유, 컵라면 등으로 대체되어 지급하는 등의 사례34)가 발생하여 예비군들의 불 평불만을 야기시키는 등 작전에 있어서 매우 부정적인 영향을 미쳤다. 이는 곧 전투력에 영향을 미 치기에 먹는 문제에 대해서는 고민하고 개선을 통해 선승구전의 자세로 임해야 한다. 지역예비군 급식지원은 예비군중대장들의 업무 영역으로만 인식해 현역 부대에서 방치하는 경우가 많은데 한 계가 있으므로 대대장들이 직접 나서서 지방자치단체 조례 등에 급식지원 관련 사항을 명확히 반

33) 합동참모본부(2019). 지역방위작전 지침서. 서울, p. 6장-10-2.

34) 육군 교육사령부(2011, pp. 5-9). 대침투작전간 통합방위작전 사례에 관한 연구-강릉작전 및 부여작전을 중심으로. 충남: 교육사령부. 
영하는 등의 노력도 필요하다.

\subsection{4 법령 및 제도 개선}

첫째, 국군조직법에 예비군을 국군의 조직에 포함시켜야 한다. 현재 예비군은 국군조직법상 국군 외 조직으로 국군의 신분을 보장받지 못하고 있다. 국군조직법 제 2 조 1 항에서는 ‘국군은 육군, 해군 및 공군(이하 '각군'이라 한다)으로 조직하며, 해군에 해병대를 둔다.'고 규정하고 있다. 유사시 군 복을 입고 임무수행을 하지만 국군이 아닌 존재라는 신분이 애매하며 예비군은 예비군법에 의해 구성된 조직으로 예비군에 대한 육성 및 지원 책임은 ‘국가기관 및 지방자치단체의 장, 직장의 장' 으로 규정하고 있어 군복은 입지만 이를 위한 책임은 군에 없는 것으로 여겨지고 있다. 예비군 군 조직의 제외, 신분적 모호, 건설 및 운영 등 법체계의 이원화로 인한 영향은 군은 물론 국민의 인식 에 지대한 영향을 미친다. 또한, 군조직이 아니라 국방정원에 포함되지 않고 예비군부대에 대한 편 제도 없는 실정이다. 따라서 예비군 정예화 완성을 위한 첫 단추는 예비군을 국군조직법상에 군 조 직으로 포함시키는 것이라고 할 수 있으며 현재 국방부에서 추진하고 있는 비상근복무 예비군도 정원에 포함시킬 수 있도록 법 개정을 추진해 나가야 한다.

둘째, 예비전력 관련 법령의 통합이다. 관련 법령들을 살펴보면 예비군의 설치 및 운영에 관해서 는 예비군법으로 규정하고 있고 전시 병력 동원에 관한 법은 병역법으로 규정하고 있다. 예비군이 라는 동일한 신분을 대상으로 하는 법령임에도 불구하고 소집대상에 따라 달라지고 권한, 실행 절 차가 각각 다르게 규정되어 있어 혼란스럽기에 이 두 가지를 통합할 수 있는 예비전력 법률을 제정 이 필요하다. 예비군법과 병역법으로 분산되어 있는 법령을 가칭 통합 예비군법으로 통합하여 체계 화시키고 법적인 완결성을 기한다면 문제가 없을 것으로 판단된다.

마지막으로 다양한 위협에 효율적 대응을 위한 법령 개정이다. 예비군법상에 임무에 비전통적 위협대비와 재해재난 관련 사항을 추가하며 재난안전관리법에 국가 재난 관련 예비군 동원 가능 포함시키는 등 보완이 필요하다. 또한 국방동원업무에 관한 훈령에 재난 동원 대상자 및 운영에 관 한 사항에 대한 구체화가 필요하며 예비군 교육훈련에 관한 훈령에 재해재난 등 비전통 위협 관련 과목이 추가 등을 검토할 필요가 있다. 미국 예비군의 경우 1920 년 국가방위법 제정으로 정규군과 주방위군, 연방예비군을 포함하는 일원화된 조직체계를 갖추고 1973년 모병제 전환에 따라 총체전 력을 도입한 결과 이라크 - 아프간전쟁에 투입되어 성공적으로 임무를 수행하였다.35) 미국의 사례 에서 보듯이 예비전력 정예화는 필요조건이며 이를 위해 예비군이 국군에 포함될 수 있도록 국군 조직법 등의 개정과 이원화된 예비군 법령 통합이 필요하며 이를 위해 미국 사례를 검토해야 할 필요가 있다.

35 ) 합동참모본부(2019), 지역방위작전 지침서. 서울, p. 6장-10-2. 


\section{V. 결론 및 논의점}

21세기의 안보환경은 미국 주도의 국제질서가 유지되는 가운데 신흥국들의 부상으로 국제체제 다극화가 가속화되고, 자국 우선주의의 대외정책으로 다자간의 협력관계가 약화되고 있으며 주요 국가 간의 전략적 협력과 경쟁이 진행되어 안보불안정성이 심화되는 양상이다. 특히, 중국은 ‘강군 몽(强軍夢)', 일본의 ‘군사대국화’, 러시아의 ‘신동방정책' 등의 추진으로 한반도 주변국의 군사력 증강이 가속화되고 있으며 북한의 군사위협이 지속되는 상황으로 이에 대한 대비가 필요하다.

군의 존재 목적은 전쟁에서 싸워 이기는 것이며, 싸우지 않고서도 이길 수 있도록 평시부터 전력 을 육성하고 연마해야 한다. 국력의 핵심인 군의 전력은 상비전력과 예비전력으로 구성되는데 우리 군은 지금 국방개혁을 통해 현존 및 미래 위협에 대비할 수 있는 충분한 전력을 구비하기 위해 노 력하고 있으며 상비전력에 버금가는 예비전력 육성을 위해 현대화 - 첨단화를 통해 내실화를 기하 고 있다. 하지만 예비군 창설 53년이 흐른 지금도 우리나라의 예비전력이 '적과 싸워 이길 수 있는 모습’을 갖추었는지 물어본다면 선뜻 답변하기는 어렵다. 이에 본 연구논문은 이와 같은 안보환경 을 고려하여'싸워 이길 수 있는 '미래 지역예비군 최적화 운영에 관하여 심층적으로 연구하였으며, 주요 결과는 다음과 같다.

첫째, 지역예비군 임무에 대한 재정립이 필요하다. 그동안 예비군의 임무는 1968년 창설 이래 큰 변화 없이 유지되어 왔다. 시대적인 흐름과 사회환경의 변화를 고려하여 국가적 재난(대형 인명사 고, 자연재해) 등 비군사적 지원이 가능토록 개선이 필요하며 무장소요 진압 등과 같은 임무는 삭 제가 필요하다. 또한 국민의 생명과 재산 보호 임무 등을 추가해 미래를 준비하는 지역예비군으로 서의 임무를 포함하는 등 재정립이 필요하다.

둘째, 작전환경 변화에 맞는 지역예비군 조직 - 편성 최적화 운용이 요구된다. 과거 읍 - 면 - 동 단위 운용개념에서 벗어나 지역방위사단의 관할지역을 고려하여 광역시 - 도로 작전지역을 확대할 필요가 있으며 지역예비군 소요는 예비군 자원 수, 지역 내 핵심방호시설 등을 고려하여 수임군 부 대별 보유기준을 마련해야 한다. 지역예비군 편성은 단계적으로 개편을 추진하며, STEP 1 은('25 년) 지역방위사단 개편과 연계하여 여단별 1 개 예비군대대를 창설 및 운영하며 여단 예속부대로 임무를 수행한다. STEP 2는('30년) 예비군 방위여단을 창설하여 기존 예비군대대를 예비군 방위대 대로 개편하여 운용한다. 임무는 비전통 위협에 대한 대응과 상황 발생 시 지역방위대대를 지원하 여 중요시설 방호 및 경계지원 등의 임무를 수행하는 것이다. 주요직위자에 대한 보강도 필요한데 예비전력관리군무원 직급을 다단계화하여 정원을 늘리는 방법과 현재 추진하고 있는 비상근 예비 군제도를 활용하는 방법을 검토할 필요가 있다. 아울러 희소특기 병사는 유사특기로 지정할 수 있 도록 지침을 개정을 검토해야 한다.

셋째, 전투력을 발휘할 수 있는 조직으로 만들기 위한 지역예비군 교육훈련에 대한 검토가 필요 하다. 훈련을 통해 습득된 전투기술을 얼마나 잘 유지하느냐가 예비전력 전투력에 직접적인 영향을 
미치는 것을 고려하여 지역예비군의 훈련을 2 개월 단위로 훈련을 하며 훈련시간은 연 36 시간으로 늘려야 한다. 상황발생 시 지급받는 총기로 훈련을 실시하며 재해재난 - 테러 등에 대비한 과제 등 을 선정하여 훈련할 필요가 있다. 작계훈련은 작전지역의 도시화를 고려하여 과학화훈련장을 이용 하여 훈련할 수 있도록 훈련장을 개선해야 한다. 지휘통제훈련 숙달이 필요한데 대대 동원훈련 시 지역예비군 작계훈련을 동시에 하는 방안 등을 검토하여 실상황과 같은 조건에서 현재의 지휘통제 가 가능한 것인지 검토하고 이를 보완하는 방향으로 교육훈련을 개선 및 발전시켜야 한다.

넷째, 지역예비군 전투력을 발휘하기 위한 장비 - 물자 개선이 시급하다. 예비군 창설 이후 현역 에서 퇴역하는 장비를 활용한 전력화 추진으로 30년 이상 노후된 장비 및 물자를 보유 및 사용하고 있다. 현역 시절과 다른 구형 장비 사용으로 예비군들의 숙달시간과 구형장비 정비에도 많은 노력 이 낭비되고 있어 개선이 요구된다. 예비군중대는 전투효율성을 고려하여 개인화기, 조준경 등의 장비 현대화를 추진하며 기동대는 현재 육군에서 추진하고 있는 워리어 플랫폼을 적용하여 미래 작전환경에 대비해야 한다. 또한, 장비 - 물자 구매방법 개선도 필요한데 장비 계약 시 수임군부대 에서 하던 계약을 군수사로 이관하는 등 업무의 전문성을 고려한 조정이 필요하며 육성지원금으로 구매한 장비도 정비 - 관리가 가능하도록 지침을 개선하여 최상 상태로 장비 - 물자를 유지할 수 있 는 시스템 구축이 필요하다.

다섯째, 현실 가능한 지원 급식지원체계 구축이 필요하다. 농 - 어촌 지역의 식당은 도시지역과 다르게 규모도 작고 대규모 인원 급식을 위한 부식준비도 제한이 되기에 이를 고려한 선정이 필요 하고 전시 미운용 시의 대책도 마련해야 한다. 아울러 주민 철수지역의 지역예비군은 군 급식도 제 한되어 급식 대형업체 동원 및 군 급식지원대 편성 - 운용을 통해 급식을 시스템적으로 지원하고 점검하는 방법들을 강구해야 한다. 작계훈련 시 작전지역에 예비군들 투입 후 지방자치단체와 함께 급식을 지원하는 등 작전계획에 기초한 급식지원을 통해 미흡사항을 보완하는 등의 노력이 필요하다.

마지막으로 21세기 안보환경 변화에 부합하고 상비전력 감소를 실질적으로 대체하기 위한 법령 및 제도 개선이 필요하다. 국군조직법상 예비군을 국군의 조직에 포함하여 건설 - 운영이 가능토록 법 개정이 필요하며 예비군법과 병역법으로 이원화된 법체계를 통합 예비군법으로 통합하여 운용 할 필요가 있다. 예비군이라는 동일한 복무제도에 동원예비군과 지역예비군으로 나누어져 보상과 복지, 작전지속지원에도 차이가 발생하여 전투력에 부정적인 영향을 미칠 수 있다. 이를 위해 법체 계를 통합 예비군법(가칭)으로 통합하고 운용 측면에서 예비군을 구분하되 작전지속지원, 복지 및 보상 등은 동일하게 제공해야겠다. 마지막으로 다양한 위협에 효율적으로 대응하기 위해 예비군법, 재난안전관리법 등에 비전통 위협에 대비한 재해재난 관련 사항을 추가하는 등의 보완이 필요하다.

이를 종합해 보면 미래 지역예비군의 최적화 운영을 위해서는 조직·편성 정비, 교육훈련 개선 등의 노력도 필요하지만, 국군조직법 등의 법률 개정이 동시에 이루어져야 가능하리라 판단된다. 본 연구는 미래 변화하는 안보환경에 대비한 지역예비군의 최적화 운영을 위해 지역예비군 전반에 대한 문제점을 운영체계, 작전지속지원체계, 법과 제도 측면에서 종합적으로 검토하고 개선사항을 
제시하였다는 점에서 학술적으로 시사점이 있다. 이는 지역예비군을 싸워 이길 수 있는 전투부대로 육성하는데 긍정적인 측면으로 작용할 것으로 생각한다.

특히, 본 연구는 미래 안보환경 변화에 대비한 예비전력 정예화의 목표달성 측면에서 군사학 연 구분야의 무형 군사력 유지 관련 주제(Bae, Ku, Park, \& Kim, 2020; Lee, J. G., 2020)와 관련된 지 역예비군 최적화 운영 방안을 제안한 초기 연구로 지금까지 관심이 부족한 연구주제를 다루었다는 점에서 학술적인 의의가 크다고 볼 수 있다. 그럼에도 향후 연구는 지역예비군 분야별로 구분하여 구체화된 연구설계와 전문가의 의견조사와 이해관계자 설문(예비군 운영 부대 구성원, 예비군 훈련 참가자 등)을 통한 종합적인 의견수렴을 통해 지역예비군 전력의 최적 운영방안을 지속적으로 연 구할 필요가 있다.

\section{Acknowledgements}

We would like to thank Editage (www.editage.co.kr) for English language editing.

\section{Declaration of Conflicting Interests}

The author(s) declared no potential conflicts of interest with respect to the research, authorship, and/or publication of this article. 


\section{Reference}

Bae, S. H., Ku, X, Y., Park, C. B., \& Kim, J. S. (2020). A Latent Topic Modeling approach for Subject Summarization of Research on the Military Art and Science in South Korea. Korean Journal of Military Art and Science, 76(2), https://doi.org/181-216. 10.31066/kjmas.2020.76.2.008

Choi, B. O., \& Park, C. H. (2014). Policy Issues and Directions for Establishing Elite Reserve Forces: Focused on Reservist Training and Education. Journal of National Defense Security, 57(4), 157-184. 10.23011/jnds.2014.57.4.006

Choi, S. H. (2020). Efficient Disaster Response Using Reserve Forces: Focusing on the US National Guard. Crisisonomy, 16(1), https://doi.org/105-120.10.14251/crisisonomy. 2020.16.1.105

Jeong, H. S. (2019). Focusing on the research on the size of reserve forces based on the mission and the plan to promote elite reserve forces in connection with Defense Reform 2.0. National Defense University Security Program Paper.

Jeong, J. S. (2018). A study on the operation of reserve forces after the unification of Korea : focusing on judgment the scale of reserve forces and establishment system [Doctoral dissertation]. Wonkwang University, Iksan.

Joo, Y. Y. (2017). A Study on the Policy Decision Process of the Establishment of Reserve Forces. Journal of Military History Studies, 143, 247-285. https://doi.org/10.17934/jmhs.. 143.201706.247

Kang, Y. G. (2019). A study on the direction of implementation of reserve power policy according to changes in the security environment in the 21st century [Doctoral dissertation]. Wonkwang University, Iksan.

Kim, M. S. (2019). Direction of development of preliminary power in all and all time following the promotion of defense reform: Focusing on the operation of regional reserve forces. A research paper at Joint Military University.

Koo, W. G., \& Park, H. H. (2019). Improving the Korea Reserve Forces System In Benchmarking the Reserve Forces System of Singapore. Journal of Military History Studies, 148, 375-402. https://doi.org/10.17934/jmhs..148.201912.375

Lee, J. G. (2020). A literature review of recent topics in Korean Military Art and Science. Journal of Advances in Military Studies. 3(3), 187-211. https://doi.org/10.37944/jams.v3i3.87 
Lee, K. P. (2017). Future Local Defense Operation Development Plan: Focusing on the operation of local reserve forces. National Defense University Security Program Paper.

Lee, W, H. (2015). The Theory and Substance of Preliminary Power. Daejeon: Chungnam National University Publishing Cultural Center.

Park, J. G. (2020). Analysis on the Necessity and Probability of Reserved Forces Deployment. Korean Journal of Military Art and Science, 76(2), 303-340. https://doi.org/10.31066/ kjmas.2020.76.2.013

Shin, D. \& Jung, C. Y. (2016). Proposal for elite Korean reserve forces through the development of U.S. reserve forces. Korea Defense Issue \& Analysis, 1650(16-54), 1-8. https://www.kida.re.kr/frt/board/frtNormalBoardDetail.do?sidx=382\&idx=1704\&depth=4\&s earchCondition=\&searchKeyword=\&pageIndex $=1$ 
IDAP 광운대항ㄱㄱㅛ 방위사업연구소

2021, Vol. 4, No. 3, 21-51.

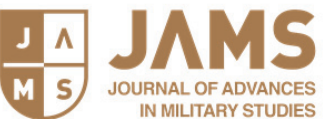

https://doi.org/10.37944/jams.v4i3.121

\section{미래 안보환경 변화를 고려한 지역예비군 최적화 운영에 관한 연구}

\section{양승봉*}

\section{국문초록}

1968년 창설된 예비군은 사회적 - 정책적 변화에 순응하면서 법령 및 제도 개선, 조직·편성 최적화 등 지속적인 변화를 통해 오늘에 이르고 있다. 그러나 국방개혁 추진에 따른 상비전력의 감축, 작전환 경 변화, 작전 수행에 필요한 예비군 자원의 감소는 지역예비군 운영개념에 대한 재정립을 요구하고 있다. 본 연구는 지역예비군의 현상을 진단하고 변화되는 미래 안보환경 변화를 고려하여 지역예비군 최적화 운영방안을 도출하기 위해 지역예비군에 대해 운영체계, 작전지속지원체계, 법과 제도 세 가지 측면에서 분석하고 개선해야 할 소요를 도출하였다. 운영체계에서는 작전환경에 맞는 지역예비군의 임무와 미래를 대비한 조직·편성 정비 그리고 교육훈련을 통한 전투력 유지 및 발전에 대해서 제시 하였고 작전지속지원체계에서는 장비 및 물자의 현대화, 급식지원체계의 시스템 보완을 제시하였다. 마지막으로 법과 제도에서는 지역예비군을 운영 및 건설하고 재정립된 임무를 고려한 법령 개정방안 을 제시하였다.

주제어 : 지역예비군, 예비전력, 안보환경, 운영체계, 작전지속지원체계, 국군조직법

* (제1저자) 국방대학교 예비전력연구센터 연구원, 원광대학교 군사학과 박사과정, 7co-zzang@hanmail.net, https://orcid.org/0000-0001-7955-1187 
